\title{
Foldamers of $\beta$-peptides: conformational preference of peptides formed by rigid building blocks. The first MI-IR spectra of a triamide nanosystem
}

\author{
Gábor Pohl ${ }^{1,2}$, Esther Gorrea ${ }^{3}$, Vicenç Branchadell ${ }^{3}$, Rosa M. Ortuño ${ }^{3}$, András Perczel ${ }^{1,2}$ and \\ György Tarczay ${ }^{4}$
}

(1) Laboratory of Structural Chemistry and Biology, Institute of Chemistry, Eötvös University, P.O. Box 32, Budapest 112, 1518, Hungary

(2) Protein Modelling Group MTA-ELTE, Institute of Chemistry, Eötvös University, P.O. Box 32, Budapest 112,1518 , Hungary

(3) Department of Chemistry, Universitat Autònoma de Barcelona, Cerdanyola del Vallès, 08193 Barcelona, Spain

(4) Laboratory of Molecular Spectroscopy, Institute of Chemistry, Eötvös University, P.O. Box 32, Budapest 112,1518 , Hungary

\section{Introduction}

Although dynamic on a large timescale of motion, some biologically active polyamide nanosystems adopt welldefined 3D structures in a time average manner, called as globular proteins; a given name reflecting to their overall shape. Other proteins called intrinsically unstructured or dynamic (IUP or IDP) are reluctant to present such an easy to characterize structural ensemble, nicknamed as proteins with random structures. Thus, proteins exist in most phases as conformational ensembles presenting lower, while in other environment higher time average deviation from their average 3D folds. The $\alpha$-amino acid sequence modification of these inherently dynamic polyamide systems can lower, or increase the amplitude and frequency of such internal motion, making the protein fold less or more "mobile". The chemical constitution $(\alpha)$ and the stereochemistry $(L)$ of proteogenic amino acid residues are under strict evolutional conservation. Unlike L-Proline, all the remaining 19 common residues in proteins have two adjacent backbone torsional angles, $\varphi$ and $\psi$, of high rotational freedom followed by the inflexible $\omega$. The scenario of two flexible followed by a fixed backbone torsional angles per residue determines primarily the folding ability of a proteogenic polypeptide. Cutting of a globular fold seldom results in secondary structural elements (e.g. $\alpha$-helix, $\beta$-turn) of low internal dynamics! Typically the removal of any secondary structural element from its "natural environment" results in polypetides of very elevated internal dynamics, often characterized as unstructured subunits. However, bioengineering requires stable toolkits to design epitopes, matching complementary folds, individual foldamers, nano-lego elements etc. of traceable shape and of low internal mobility.

Shedding light on folding and stability of secondary structural elements of peptides and proteins could help to design standalone foldamers. They could be composed of $\beta-, \alpha$ - and $\alpha / \beta$-amino acid residues, the latter called chimera. A general expectation of foldamers is to present a single time average $3 \mathrm{D}$-structure of lower internal dynamics over the large timescale of picoseconds to second. These fold optimized biocompatible and nonnatural peptides often have an increased proteolytic and metabolic stability and can fulfill diverse biological functions toward DNA, RNA, ATP, etc. The improved ability of $\beta$-peptides and thus $\beta$-foldamers to rapidly and spontaneously fold $(<\mathrm{ns})$ triggered a research field of growing interest; the rational design of foldamers. The use of chiral four-, five- and six-membered carbocycles as a molecular scaffold has been successfully introduced to synthesize $\beta^{2,3}$-disubstitued $\beta$-peptides. Beside their flexible $\varphi$ and $\psi$ backbone torsional angles, the central $\mu(\mathrm{N}-$ $\mathrm{C}^{3}-\mathrm{C}^{2}-\mathrm{CO}$ ) dihedral angle has a limited mobility as part of the carbocycle. In addition, this dihedral angle has either a cis or a trans conformation also governing the gauche or antidisposition of the $\mathrm{X}-\mathrm{N}-\mathrm{C}^{3}-$ and $-\mathrm{C}^{2}-\mathrm{CO}-$ $\mathrm{Y}$ fragments of the molecules, narrowing down the conformational freedom of both $\varphi$ and $\psi$. Thus, point chirality of the carbocyclic residues plays a crucial role in the backbone fold predetermination of these $\beta$ peptides.

The homopolymer of the cis stereoisomer of 2-aminocyclobutane-1-carboxylic acid (ACBA), $(R, S)$-1, forms exclusively a six-membered hydrogen-bonded foldamer (e.g. $\left[\mathrm{Z}_{6}{ }^{\mathrm{P}}\right]$, Torres et al. 2010), while that of thetrans $(S, S)$ adopts a helical fold (Fernandes et al. 2010). In ACBA polymers of mixed chirality, a structural transition between the aforementioned twofold was hypothesized for the cis-trans isomer, never reported previously. The local chirality controlled global fold preference prompted a systematic research on how local 
stereochemistry precludes the formation of mixed or inherently flexible secondary structures for $\beta$-peptides composed of [ACBA] $n$ (Torres et al. 2009; Gorrea et al. 2012). However, the bases of a rigid scaffold design and the predictive power of such an approach strongly relies on the exact and explicit knowledge of the conformational preference of ACBA building units. Even though the structural properties of ACBA oligomers were thoroughly analyzed by NMR and QM methods (Torres et al. 2009), the precise abundance of all forms of these building units needs now to be proven experimentally. Although the QM and NMR results agreed well, the latter technique only measures on a conformational average, and thus it unravels properties of the individual foldamers. Matrix-isolation IR (MI-IR) spectroscopy, the technique used in the present study, allows us to identify each conformer and gain a full picture of the conformational pool of these cyclic $\beta$-amino acids.

Conformational landscapes of biopolymers are often studied by combining quantum chemical calculations and vibrational spectroscopic measurements. In order to get the best correlation between computations and experiments, molecules have to be examined with no or minimal intermolecular interactions, e.g. in the gas phase. In practice this usually means jet-cooled laser spectroscopic investigations, which has the drawback that it requires the presence of a chromophoric group. To avoid this, molecules can alternatively be studied by conventional IR spectroscopy in a low-temperature inert noble gas matrix. In case of a relatively large barrier between the different conformers and by applying fast freezing during deposition the gas-phase distribution of conformers is conserved in the matrix. Several examples prove that MI-IR spectroscopy is a powerful tool for studying the conformational landscape of biomolecules, including amino acid and small peptide models. The first MI-IR spectroscopic investigations on amino acid residues were performed by Grenie et al. (1970), who studied glycine (Gly) in an Ar matrix. Since then Gly (Grenie and Garrigou-Lagrange 1972; Reva et al. 1995; Stepanian et al. 1998a; Ivanov et al. 1997, 1999; Bazsó et al. 2012a,b) and many other amino acids were thoroughly studied by MI-IR spectroscopy, including alanine (Rosado et al. 1997; Stepanian et al. 1998b; Lambie et al. 2003; Bazsó et al. 2013), valine (Stepanian et al. 1999), leucine (Sheina et al. 1988), isoleucine (Boeckx and Maes 2012a), proline (Reva et al. 1994; Stepanian et al. 2001), serine (Lambie et al. 2004; Jarmelo et al. 2005; Jarmelo et al. 2006), phenylalanine (Kaczor et al. 2006), tyrosine (Ramaekers et al. 2005), tryptophan (Kaczor et al. 2007), cysteine (Dobrowolski et al. 2007), asparagine (Boeckx and Maes 2012b), lysine (Boeckx and Maes 2012c), and $\beta$-alanine (Rosado et al. 1997; Dobrowolski et al. 2008). In a step towards understanding the structure and folding of peptides, protected amino acids, the smallest peptide models, were also investigated by this technique, including $N$-formylglycine (For-Gly, Wierzejewska and OlbertMajkut 2009), $N$-acetylglycine (Ac-Gly, Boeckx and Maes2012d), $N$-acetylalanine (Ac-Ala, Boeckx and Maes 2012e), $N$-acetyproline (Ac-Pro, Boeckx et al. 2011), $N$-acetylcysteine (Ac-Cys, Boeckx et al. 2010), $N$ acetyl- $N$ '-methyl-glycine-amide (Ac-Gly-NHMe, Grenie et al.1975; Pohl et al. 2007), $N$-acetyl- $N{ }^{\prime}$-methyl-Lalanine-amide (Ac-L-Ala-NHMe, Grenie et al. 1975; Pohl et al.2007), and their water complexes (Tarczay et al. 2009), furthermore $N$-acetyl-L-proline-amide (Ac-L-Pro- $\mathrm{NH}_{2}, \quad$ Pohl et al. 2008), $N$-acetyl-3aminopropionic acid- $N^{\prime}$-methylamide (Ac- $\beta$-HGly-NHMe, Beke et al. 2009), $N$-acetyl-3-aminobutanoic acid- $N^{\prime}-$ methylamide (Ac- $\beta$-HAla-NHMe, Beke et al. 2009), 2-[(2S)-1-acetylpyrrolidin-2-yl]- $N$-methylacetamide (Ac- $\beta$ HPro-NHMe, Góbi et al. 2010).

Our present aim is to determine the conformational distribution of (ACBA) derivatives by MI-IR spectroscopy and to show that the local chirality of the building block fully controls their folding preferences. For this purpose, building units $(S, R)-\mathbf{1}$ and $(S, S)-\mathbf{2}$ as well as for the first time two dipeptides or triamides, namely $(S, R, S, S)-\mathbf{3}$ and $(S, S, S, R)-\mathbf{4}$ (Fig. 1) were considered. Here we focus on how different secondary structure types could be designed to tie linkers and foldamers to match biochemist requirements. These results could be useful to identify structural building blocks for rational design of foldamer(s).

\section{Experimental and computational methods}

\section{Synthesis of the model compounds}

The syntheses of monomers $(S, R)-\mathbf{1}$ and $(S, S)$-2 were described in details in a former publication (Gorrea et al. 2012). To remove the traces of the solvents and other volatile impurities, the samples were lyophilized for about $24 \mathrm{~h}$, and then heated for several hours in high vacuum at a temperature just below the sublimation point of the peptide sample.

Dimers (S,R,S,S)-3 and $(S, S, S, R)-\mathbf{4}$ are new compounds. These were chosen for the present investigations because these compounds are more volatile than the previously investigated Boc derivatives (Torres et al.2009; Gorrea et al. 2012). It is expected that the nature of the N-protecting group might slightly, but not substantially change the conformational distribution.

\section{Synthesis of $(S, R, S, S)-3$}


To a solution of compound 5 (0.33 g, $1.01 \mathrm{mmol}$ ) (Scheme 1), prepared according to Gorrea et al. (2012), in anhydrous $\mathrm{CH}_{2} \mathrm{Cl}_{2}, \mathrm{Et}_{3} \mathrm{SiH}(0.21 \mathrm{~mL}, 1.31 \mathrm{mmol}, 1.3 \mathrm{eq})$ and TFA (1.01 mL, $\left.13.14 \mathrm{mmol}, 13.0 \mathrm{eq}\right)$ was added at room temperature, and the mixture was stirred for $2 \mathrm{~h}$. The organic solvent was evaporated under reduced pressure and the excess of TFA was eliminated by lyophilization. The crude obtained ( $0.33 \mathrm{~g}$, quantitative yield $)$ was used in the next step without further purification. A solution in EtOAc containing the free amine $(0.33 \mathrm{~g}$, $1.01 \mathrm{mmol})$, DMAP $(25 \mathrm{mg}, 0.20 \mathrm{mmol}, 0.2 \mathrm{eq}), \mathrm{Et}_{3} \mathrm{~N}(0.35 \mathrm{~mL}, 2.53 \mathrm{mmol}, 2.5 \mathrm{eq})$ and $\mathrm{Ac}_{2} \mathrm{O}(0.10 \mathrm{~mL}$, $1.01 \mathrm{mmol}, 1.0 \mathrm{eq}$ ) was stirred at room temperature overnight. Afterwards, the solvent was removed, and the crude obtained was washed with hot EtOAc, being the desired product insoluble in that solvent. In addition, the product was purified by column chromatography using 10:1 dichloromethane-methanol as eluent, obtaining the $N$-Ac peptide $(0.17 \mathrm{~g})$ in $63 \%$ yield, whose ${ }^{1} \mathrm{H}$ and ${ }^{13} \mathrm{C}$ NMR spectroscopic data were consistent with the expected product. ${ }^{1} \mathrm{H}$ NMR $\left(250 \mathrm{MHz}, \mathrm{CDCl}_{3}\right): \delta 1.76-2.38$ (c.a., $11 \mathrm{H}, \mathrm{Me}_{1}, \mathrm{H}_{5 \mathrm{R}}, \mathrm{H}_{5 \mathrm{~S}}, \mathrm{H}_{6 \mathrm{R}}, \mathrm{H}_{6 \mathrm{~S}}, \mathrm{H}_{11 \mathrm{R}}, \mathrm{H}_{11 \mathrm{~S}}, \mathrm{H}_{12 \mathrm{R}}$, $\mathrm{H}_{12 \mathrm{~S}}$ ), $3.01\left(\mathrm{q},{ }^{3} \mathrm{~J}_{\mathrm{H}-\mathrm{H}}=8.9 \mathrm{~Hz}, 1 \mathrm{H}, \mathrm{H}_{13}\right), 3.20\left(\mathrm{~m}, 1 \mathrm{H}, \mathrm{H}_{7}\right), 3.68\left(\mathrm{~s}, 3 \mathrm{H}, \mathrm{Me}_{15}\right), 4.44-4.74$ (c.a., $\left.2 \mathrm{H}, \mathrm{H}_{4}, \mathrm{H}_{10}\right), 5.97$ $\left(\mathrm{d},{ }^{3} \mathrm{~J}_{\mathrm{H}-\mathrm{H}}=7.1 \mathrm{~Hz}, 1 \mathrm{H}, \mathrm{NH}_{9}\right), 6.39\left(\mathrm{~d},{ }^{3} \mathrm{~J}_{\mathrm{H}-\mathrm{H}}=6.9 \mathrm{~Hz}, 1 \mathrm{H}, \mathrm{NH}_{3}\right) .{ }^{13} \mathrm{C} \mathrm{NMR}\left(62.5 \mathrm{MHz}, \mathrm{CDCl}_{3}\right): \delta 18.57,18.74$, 27.26, $28.48\left(\mathrm{C}_{5}, \mathrm{C}_{6}, \mathrm{C}_{11}, \mathrm{C}_{12}\right), 23.23\left(\mathrm{C}_{1}\right), 45.29,46.07,46.64,47.49\left(\mathrm{C}_{4}, \mathrm{C}_{7}, \mathrm{C}_{10}, \mathrm{C}_{13}\right), 51.99\left(\mathrm{C}_{15}\right), 170.17$ $\left(\mathrm{CO}_{\mathrm{st}}\right), 172.32\left(\mathrm{CO}_{\mathrm{st}}\right), 173.33\left(\mathrm{CO}_{\mathrm{st}}\right)$.

To an ice-cooled solution of the obtained product $(0.17 \mathrm{~g}, 0.63 \mathrm{mmol})$ in $1: 10 \mathrm{THF}$-water $(55 \mathrm{~mL}), 0.25 \mathrm{M}$ sodium hydroxide aqueous solution $(6.3 \mathrm{~mL}, 1.58 \mathrm{mmol}, 2.5 \mathrm{eq})$ was added and the resultant mixture was stirred for $2 \mathrm{~h}$ (reaction progress was monitored by TLC). The reaction mixture was acidified by adding $5 \% \mathrm{HCl}$ aqueous solution to reach $\mathrm{pH}$ 2. Then, the acid solution was evaporated and the excess of water was lyophilized. The product was identified by ${ }^{1} \mathrm{H}$ NMR and the crude was used directly in the next synthesis step without further purification. ${ }^{1} \mathrm{H}$ NMR $\left(250 \mathrm{MHz}, \mathrm{CDCl}_{3}\right): \delta 1.76-2.38$ (c.a., $11 \mathrm{H}, \mathrm{Me}_{1}, \mathrm{H}_{5 \mathrm{R}}, \mathrm{H}_{5 \mathrm{~S}}, \mathrm{H}_{6 \mathrm{R}}, \mathrm{H}_{6 \mathrm{~S}}, \mathrm{H}_{11 \mathrm{R}}, \mathrm{H}_{11 \mathrm{~S}}, \mathrm{H}_{12 \mathrm{R}}$, $\mathrm{H}_{12 \mathrm{~S}}$ ), $3.01\left(\mathrm{q},{ }^{3} \mathrm{~J}_{\mathrm{H}-\mathrm{H}}=8.9 \mathrm{~Hz}, 1 \mathrm{H}, \mathrm{H}_{13}\right), 3.20\left(\mathrm{~m}, 1 \mathrm{H}, \mathrm{H}_{7}\right), 3.68\left(\mathrm{~s}, 3 \mathrm{H}, \mathrm{Me}_{15}\right), 4.44-4.74$ (c.a., $\left.2 \mathrm{H}, \mathrm{H}_{4}, \mathrm{H}_{10}\right), 5.97$ $\left(\mathrm{d},{ }^{3} \mathrm{~J}_{\mathrm{H}-\mathrm{H}}=7.1 \mathrm{~Hz}, 1 \mathrm{H}, \mathrm{NH}_{9}\right), 6.39\left(\mathrm{~d},{ }^{3} \mathrm{~J}_{\mathrm{H}-\mathrm{H}}=6.9 \mathrm{~Hz}, 1 \mathrm{H}, \mathrm{NH}_{3}\right)$. In a solution of the free acid thus prepared $(0.17 \mathrm{~g}, 0.67 \mathrm{mmol})$ in DMF $(5 \mathrm{~mL}) 2.0 \mathrm{M}$ methylamine solution in THF $(0.5 \mathrm{~mL}, 1.00 \mathrm{mmol}, 1.5 \mathrm{eq})$, FDPP $(0.31 \mathrm{~g}, 0.80 \mathrm{mmol}, 1.2 \mathrm{eq})$ and DIPEA $(0.34 \mathrm{~mL}, 2.01 \mathrm{mmol}, 3.0 \mathrm{eq})$ were successively added. The mixture was stirred overnight and then the solvent was lyophilized. Afterwards, the crude obtained was washed with EtOAc. The remaining white solid $(0.15 \mathrm{~g}, 84 \%$ yield) was identified as the desire product $(S, R, S, S)-3$ and fully characterized. Crystals (from ethyl acetate) mp: change of polymorphism at $247{ }^{\circ} \mathrm{C}$, melts at more than $280{ }^{\circ} \mathrm{C}$. $[\alpha]_{\mathrm{D}}=+123(c 0.5, \mathrm{MeOH})$. IR (ATR): 3,292 $\left(\mathrm{NH}_{\mathrm{st}}\right), 2,943\left(\mathrm{CH}_{\mathrm{st}}\right), 1,739\left(2 \mathrm{CO}_{\mathrm{st}}\right), 1,648\left(\mathrm{CO}_{\mathrm{st}}\right) .{ }^{1} \mathrm{H} \mathrm{NMR}$ $\left(360 \mathrm{MHz}, \mathrm{CDCl}_{3}\right): \delta 1.72-2.43$ (c.a., $\left.11 \mathrm{H}, \mathrm{Me}_{1}, \mathrm{H}_{5 \mathrm{R}}, \mathrm{H}_{5 \mathrm{~S}}, \mathrm{H}_{6 \mathrm{R}}, \mathrm{H}_{6 \mathrm{~S}}, \mathrm{H}_{11 \mathrm{R}}, \mathrm{H}_{11 \mathrm{~S}}, \mathrm{H}_{12 \mathrm{R}}, \mathrm{H}_{12 \mathrm{~S}}\right), 2,82\left(\mathrm{~d},{ }^{3} \mathrm{~J}_{\mathrm{H}-}\right.$ $\left.{ }_{\mathrm{H}}=4.7 \mathrm{~Hz}, 3 \mathrm{H}, \mathrm{Me}_{16}\right), 2.88\left(\mathrm{~m}, 1 \mathrm{H}, \mathrm{H}_{7}\right), 3.28\left(\mathrm{~m}, 1 \mathrm{H}, \mathrm{H}_{13}\right), 4.31\left(\mathrm{q},{ }^{3} \mathrm{~J}_{\mathrm{H}-\mathrm{H}}=7.0 \mathrm{~Hz}, 1 \mathrm{H}, \mathrm{H}_{4}\right), 4.66\left(\mathrm{q},{ }^{3} \mathrm{~J}_{\mathrm{H}-}\right.$

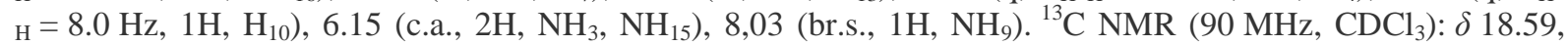
19.02, 24.54, $26.30\left(\mathrm{C}_{5}, \mathrm{C}_{6}, \mathrm{C}_{11}, \mathrm{C}_{12}\right), 23.21\left(\mathrm{C}_{1}\right) 28.26\left(\mathrm{C}_{16}\right), 45.71,45.96,48.17,49.71\left(\mathrm{C}_{4}, \mathrm{C}_{7}, \mathrm{C}_{10}, \mathrm{C}_{13}\right)$, $170.37\left(\mathrm{CO}_{\text {st }}\right), 173.94\left(2 \mathrm{CO}_{\text {st }}\right)$. HRMS calcd. for $\mathrm{C}_{13} \mathrm{H}_{21} \mathrm{~N}_{3} \mathrm{O}_{3} \mathrm{Na}(\mathrm{M}+\mathrm{Na}): 290.1475$, found: 290.1472.

\section{Synthesis of $(S, S, S, R)-4$}

Following similar procedures to those described above, dimer $(S, S, S, R)-\mathbf{4}$ was prepared from precursor 6 by removal of the $N$-Boc carbamate and acetylation of the resultant amine, to afford $(S, S, S, R)-4$ in $81 \%$ overall yield (Scheme 1). Crystals (from ethyl acetate), mp: $245-247{ }^{\circ} \mathrm{C}$, change of polymorphism at $232{ }^{\circ} \mathrm{C}$. $[\alpha]_{\mathrm{D}}=-38$ (c $0.3, \mathrm{MeOH})$. IR (ATR): 3,328 ( $\left.\mathrm{NH}_{\mathrm{st}}\right), 3,287\left(\mathrm{NH}_{\mathrm{st}}\right), 2,938\left(\mathrm{CH}_{\mathrm{st}}\right), 1,738\left(\mathrm{CO}_{\mathrm{st}}\right), 1,644\left(2 \mathrm{CO}_{\mathrm{st}}\right) .{ }^{1} \mathrm{H} \mathrm{NMR}$ (360 MHz, $\mathrm{CDCl}_{3}$ ): $\delta$ 1.78-2.42 (c.a., $11 \mathrm{H}, \mathrm{Me}_{1}, \mathrm{H}_{5 \mathrm{R}}, \mathrm{H}_{5 \mathrm{~S}}, \mathrm{H}_{6 \mathrm{R}}, \mathrm{H}_{6 \mathrm{~S}}, \mathrm{H}_{11 \mathrm{R}}, \mathrm{H}_{11 \mathrm{~S}}, \mathrm{H}_{12 \mathrm{R}}, \mathrm{H}_{12 \mathrm{~S}}$ ), 2,79 (s, 3H, $\mathrm{Me}_{16}$ ), $2.91\left(\mathrm{~m}, 1 \mathrm{H}, \mathrm{H}_{7}\right), 3.29\left(\mathrm{~m}, 1 \mathrm{H}, \mathrm{H}_{13}\right), 4.28\left(\mathrm{~m}, 1 \mathrm{H}, \mathrm{H}_{4}\right), 4.55\left(\mathrm{~m}, 1 \mathrm{H}, \mathrm{H}_{10}\right), 5.81\left(\mathrm{~d},{ }^{3} \mathrm{~J}_{\mathrm{H}-\mathrm{H}}=6.5 \mathrm{~Hz}, 1 \mathrm{H}, \mathrm{NH}_{3}\right), 6.05$ (br.s., $\left.1 \mathrm{H}, \mathrm{NH}_{15}\right), 8,49$ (br.s., $\left.1 \mathrm{H}, \mathrm{NH}_{9}\right) .13 \mathrm{C} \mathrm{NMR}\left(90 \mathrm{MHz}, \mathrm{CDCl}_{3}\right): \delta 18.93,19.20,25.19,26.96\left(\mathrm{C}_{5}, \mathrm{C}_{6}, \mathrm{C}_{11}\right.$, $\left.\mathrm{C}_{12}\right), 26.27\left(\mathrm{Me}_{1}\right), 29.87\left(\mathrm{Me}_{16}\right), 46.17,46.38,48.61,49.40\left(\mathrm{C}_{4}, \mathrm{C}_{7}, \mathrm{C}_{10}, \mathrm{C}_{13}\right), 170.85\left(\mathrm{CO}_{\mathrm{st}}\right), 172.86\left(\mathrm{CO}_{\mathrm{st}}\right)$, $173.64\left(\mathrm{CO}_{\text {st }}\right)$. HRMS calcd. for $\mathrm{C}_{13} \mathrm{H}_{21} \mathrm{~N}_{3} \mathrm{O}_{3} \mathrm{Na}(\mathrm{M}+\mathrm{Na}): 290.1475$, found: 290.1477.

\section{MI-IR measurements}

The lyophilized samples were evaporated into the vacuum chamber using a home-built Knudsen effusion cell. The cell is made of copper and is inductively heated by a wire; its temperature was measured by a thermocouple. The sample is placed inside the cell in a glass sample holder. The evaporated sample first enters into a $\sim 0.5 \mathrm{~cm}^{3}$ buffer chamber, and then it leaves the cell through a $1 \mathrm{~mm}$ diameter pinhole. The evaporated sample was mixed with argon (Messer, $99.9997 \%$ ) before deposition. The gas flow was kept at $0.07 \mathrm{mmol} \mathrm{min}^{-1}$, while the temperature of the Knudsen cell was optimized to obtain the shortest possible deposition time and keep the concentration low enough to minimize the formation of dimers in the matrix. The applied evaporation temperature was $350 \mathrm{~K}, 365 \mathrm{~K}, 446 \mathrm{~K}$, and $443 \mathrm{~K}$ for $(S, R)-\mathbf{1},(S, S)-\mathbf{2},(S, R, S, S)-\mathbf{3}$ and $(S, S, S, R)-\mathbf{4}$, respectively. The sample-rare gas mixture was deposited onto an 8-10 K CsI window mounted on a Janis CCS-350R cold head cooled by a CTI Cryogenics 22 closed-cycle refrigerator unit. 
MI-IR spectra were recorded by a Bruker IFS 55 FT-IR spectrometer equipped with a KBr beamsplitter. 1,0003,000 scans at $1 \mathrm{~cm}^{-1}$ resolution were accumulated by using a DTGS detector. The baseline was corrected by an adjusted polynomial function, when necessary because of interference.

\section{Computational details}

An acyclic monomeric $\beta$-amino acid residue has three backbone dihedral angles resulting in up to $3^{3}$ possible backbone folds (see the 3D Ramachandran Cube, Fig. 2). The conformational codes for each of the 27 possible conformers have already been assigned (Beke et al. 2006). H, Z, S, E letters stand for the four possible secondary structure motif (Helical, Zigzag, Spiral and Elongated, respectively; see (Beke et al.2006) for further details), superscript $\mathrm{M}$ or P signals the axial handedness or twist (P: plus or clockwise; $\mathrm{M}$ : minus or counterclockwise) of a given structure and subscript number signals the number of atoms participating in H-bonded pseudo ring. The asterisk (*) indicates "conformational permutation": the torsion angle $\mu$ remains the same, but the $\varphi$ and $\psi$ torsional angles are interchanged. For ACBA derivatives, the cyclobutane ring constrains torsion angle $\mu$ leading to the reduction of the total number of possible conformers to $3 \times 3=9$, or less backbone structures at any configuration.

\section{Results and discussion}

The computed Gibbs free energies at $0 \mathrm{~K}$ and at the temperature of evaporation together with the corresponding Boltzmann distributions of the low-energy conformers of the four compounds are listed in Table 3. The amide A and I, a representative part of the fingerprint regions of the MI-IR spectra and the computed spectra of the lowenergy conformers are shown in Figs. 6,7, 8,9. The other parts of the spectra are given in the Supporting Information. Tables 4 and 5 summarize the assignments of all the experimentally observed transitions of the MIIR spectra of $(S, R)-\mathbf{1}$ and $(S, S)-\mathbf{2}$, respectively. These assignments should be considered to be tentative for the very weak transitions, as well as in the congested $\mathrm{C}-\mathrm{H}$ stretching region. Furthermore, the assignments in the amide I region are also somewhat uncertain, because of site splitting, which is very common for $\mathrm{X}-\mathrm{H}$ stretching modes, and because of the appearance of the overtone bands of the amide I vibrations which interact with the amide A vibrational modes by Fermi resonance. In the case of $(S, R, S, S)-\mathbf{3}$ and $(S, S, S, R)-\mathbf{4}$ we do not attempt to assign all the transitions in the congested $\mathrm{C}-\mathrm{H}$ stretching and low-wavenumber $\left(>1,600 \mathrm{~cm}^{-1}\right)$ regions (see right panels in Figs. 8,9). The identification of the different conformers is based on the analysis of the amide A and amide I regions of the spectra (see left and middle panels in Figs. 8, 9).

\section{$(S, R)-1$}

According to the computations $(S, R)-\mathbf{1}$ have two low-energy conformers (see Fig. 3). One of them, $\mathrm{Z}_{6}{ }^{\mathrm{P}}$, forms a six-membered pseudo ring with intramolecular $\mathrm{H}$-bond between the $\mathrm{N}$-terminal $\mathrm{N}-\mathrm{H}$ and the $\mathrm{C}$-terminal $\mathrm{C}=\mathrm{O}$. The second one, $\mathrm{Z}_{8}{ }^{\mathrm{P}}$, is also stabilized by an intramolecular $\mathrm{H}$-bond (between the $\mathrm{C}$-terminal $\mathrm{N}-\mathrm{H}$ and the $\mathrm{N}$ terminal $\mathrm{C}=\mathrm{O})$ forming an eight-membered pseudo ring. For the temperature of evaporation $(350 \mathrm{~K}) \mathrm{B} 3 \mathrm{LYP} / 6$ $31++\mathrm{G}(\mathrm{d}, \mathrm{p})$ computations predict $60 \% \mathrm{Z}_{6}{ }^{\mathrm{P}}$ and $40 \% \mathrm{Z}_{8}{ }^{\mathrm{P}}$ in the gas phase. Since the conversion between $\mathrm{Z}_{6}{ }^{\mathrm{P}}$ and $\mathrm{Z}_{8}{ }^{\mathrm{P}}$ would require relatively high energy for the rupture of the intramolecular $\mathrm{H}$-bond, and it has a large space requirement, it is expected that the gas-phase distribution is conserved during the matrix deposition. All the bands of the MI-IR spectra can be assigned to the $\mathrm{Z}_{6}{ }^{\mathrm{P}}$ and $\mathrm{Z}_{8}{ }^{\mathrm{P}}$ conformers. Although due to the abovementioned difficulties the assignments are somewhat uncertain in the amide A region, the number of spectral bands indicate, that, even considering site splittings and overtone bands, both conformers are present in the matrix. In the amide I region computations show that the two-two amide I bands of the two conformers are very close together. In agreement with this, two intensive bands were observed in the amide I region of the MI-IR spectra. The shape of none of these two bands is symmetric, which can be caused by the closely spaced, unresolved bands of the two conformers or by site splitting. It should also be noted that a low-intensity broad band, red shifted from the amide $\mathrm{I}$ bands of the lower wavenumber amide $\mathrm{I}$ band of $\mathrm{Z}_{6}{ }^{\mathrm{P}}$ and $\mathrm{Z}_{8}{ }^{\mathrm{P}}$ were also observed. This band can be assigned to traces of intermolecular H-bonded dimers.

The presence of the two conformers in the matrix can most convincingly be proven by the analysis of the lower frequency region. For example, the right panels in Fig. 6 show the experimental and the computed spectra in the 1,190-1,290 $\mathrm{cm}^{-1}$ spectral window. Although the spectra are rather congested and the bands of the two $\mathrm{Z}_{6}{ }^{\mathrm{P}}$ and the $\mathrm{Z}_{8}{ }^{\mathrm{P}}$ conformers are close to each other, the number of peaks clearly shows that both conformers are present. When comparing the computed and the experimental frequencies as well as the relative intensities, a tentative assignment was made (Table 4). To get the best match between the computed and experimental frequencies and to get similar experimental and computed intensity patterns it had to be supposed that $\mathrm{Z}_{6}{ }^{\mathrm{P}}$ has a lower concentration in the matrix than $\mathrm{Z}_{8}{ }^{\mathrm{P}}$. This means, however, that the experimental population order has to be reversed with respect to that of computation (Table 3). Therefore, we have tried to give an alternative assignment 
(see supporting information) accepting the computed population ratios. We favor the assignments of Table 4 since it reproduces the experimental intensity patterns better, and the differences between the computed and the experimental frequencies are also smaller in this case. Accepting the tentative assignments of Table 4 a semi-experimental conformer ratio can be estimated by taking into account the ratio of the integrated area normalized by the computed intensity of selected bands of the conformers:

$n \mathrm{Z} 6 n \mathrm{Z} 8=\sum i A \mathrm{z} 6, i \mathrm{IZ6}, i / \sum j A \mathrm{z} 8, j \mathrm{IZ} 8, j$

(1)

where $A_{\mathrm{Z} 6} i$ and $A_{\mathrm{Z} 8} j$ are the experimental integrated areas of the selected bands of conformer $\mathrm{Z}_{6}{ }^{\mathrm{P}}$ and $\mathrm{Z}_{8}{ }^{\mathrm{P}}$, respectively, and $I_{\mathrm{Z} 6}, i$ and $I_{\mathrm{Z} 8} j$ are the corresponding computed intensities. For this semi-empirical estimation of conformer ratios the bands between 1,190 and 1,240 $\mathrm{cm}^{-1}$ (see Table 4) were chosen. Although these bands have relatively low intensities, according to our assignment these are among the most resolved bands of the two conformers. This analysis resulted in $15 \%$ for $\mathrm{Z}_{6}{ }^{\mathrm{P}}$ and $85 \%$ for $\mathrm{Z}_{8}{ }^{\mathrm{P}}$, respectively. A similar semiexperimental ratio $\left(12 \% \mathrm{Z}_{6}{ }^{\mathrm{P}}\right.$ and $88 \% \mathrm{Z}_{8}{ }^{\mathrm{P}}$ ) can be obtained from the computed and experimental intensities of the two more intensive amide A ( $\mathrm{N}-\mathrm{H}$ stretching) modes. At $350 \mathrm{~K}$ at B3LYP/6-31++G(d,p) computations predict $60 \% \mathrm{Z}_{6}{ }^{\mathrm{P}}$ and $40 \% \mathrm{Z}_{8}{ }^{\mathrm{P}}$ in the gas phase.

$(S, S)-2$

In contrast to $(S, R)-\mathbf{1}$, besides an eight-membered ring conformer with intramolecular H-bond $(S, S)$-2 also has a low-energy open-chain conformer, $\mathrm{S}^{\mathrm{M}}$, without intramolecular H-bond (Fig. 3). The abundance of $\mathrm{S}^{\mathrm{M}}$ is not negligible at $365 \mathrm{~K}$, at the temperature of evaporation. Based on the computational results besides $75 \% \mathrm{H}_{8}^{\mathrm{P}}$, $25 \% \mathrm{~S}^{\mathrm{M}}$ is also expected to be present in the gas phase (Table 3). (Note that the present conformational labeling is different from the notations used in Gorrea et al. (2012). The $\mu$ torsion angle in $(S, S)-\mathbf{2}$ is on the border of the gauche- and anti-regions. Gorrea et al. (2012) considered it to be gauche and named the conformers accordingly. However, the value is somewhat closer to the anti-alignment and thus in the present work the $(S, S)$ 2 conformers categorized by conformational labels of the anti-plane of the potential energy cube.

The comparison of the MI-IR and the computed spectra shows that $\mathrm{H}_{8}{ }^{\mathrm{P}}$ is predominant in the matrix. The presence of $\mathrm{S}^{\mathrm{M}}$ in the matrix can unambiguously be proven by some of its relatively intensive vibrational transitions, which are well separated from the bands of $\mathrm{H}_{8}{ }^{\mathrm{P}}$ or which have considerably larger molar absorption than the neighboring bands of $\mathrm{H}_{8}{ }^{\mathrm{P}}$. The right panels in Fig. 7 show two of these bands (computed at $1,193.6 / 1,198.7$ and $1,150.5 \mathrm{~cm}^{-1}$ ) in the $1,100-1,215 \mathrm{~cm}^{-1}$ spectral region. These two bands have almost an order of magnitude larger intensity than those of $\mathrm{H}_{8}{ }^{\mathrm{P}}$. (Note that different intensity scale is used for $\mathrm{S}^{\mathrm{M}}$ and $\mathrm{H}_{8}{ }^{\mathrm{P}}$ in this region in Fig. 7.) Although it is somewhat uncertain whether the band observed at $1,203 \mathrm{~cm}^{-1}$ or the site-split one of about the same intensity at 1,186 and $1,184 \mathrm{~cm}^{-1}$ correspond to the band of $\mathrm{S}^{\mathrm{M}}$, calculated at $1,193.6 \mathrm{~cm}^{-1}$. One of them certainly corresponds to $\mathrm{S}^{\mathrm{M}}$ and the other belongs to the band of $\mathrm{H}_{8}{ }^{\mathrm{P}}$ calculated as $1,196.0 \mathrm{~cm}^{-1}$. There are other examples for bands that can be assigned to $\mathrm{S}^{\mathrm{M}}$ (Table 5), the corresponding spectral regions are shown in the Supplementary Material.

The semi-empirical estimation of conformer ratios which were described for $(S, R)-\mathbf{1}$ was also performed for $(S, S)$-2. In this case, the bands around $1,200 \mathrm{~cm}^{-1}$ are extremely week, therefore, instead of these bands the $\mathrm{O}-\mathrm{H}$ stretching modes were used for the analysis. From this the abundance of $\mathrm{S}^{\mathrm{M}}$ is $\sim 23 \%$ in the matrix, and the rest of $(S, S)$-2, i.e. $\sim 77 \%$ is present in the $\mathrm{H}_{8}{ }^{\mathrm{P}}$ conformation. These results are consistent with the computational estimates (Table 3).

$(S, R, S, S)-3$

$(S, R, S, S)-3$ has two low-energy conformers, $\mathrm{Z}_{6}{ }^{\mathrm{P}} \mathrm{H}_{8}{ }^{\mathrm{P}}$ and $\mathrm{Z}_{8}{ }^{* \mathrm{P}} \mathrm{H}_{8}{ }^{\mathrm{P}}$, with two intramolecular $\mathrm{H}$-bonds (Fig. 4). In $\mathrm{Z}_{6}{ }^{\mathrm{P}} \mathrm{H}_{8}{ }^{\mathrm{P}}$ both the $\mathrm{C}$ - and the $\mathrm{N}$-terminal $\mathrm{N}-\mathrm{Hs}$ bond to the middle amide group's oxygen, forming six- and eight-membered rings. In $\mathrm{Z}_{8}{ }^{*}{ }^{\mathrm{P}} \mathrm{H}_{8}{ }^{\mathrm{P}}$ two eight-membered rings are formed by intramolecular $\mathrm{H}$-bonds, one is between the N-terminal carbonyl oxygen and the middle amide group's hydrogen, the other is between the C-terminal amide group's hydrogen and the group's oxygen. There are other two conformers $\left(\mathrm{Z}_{6}{ }^{\mathrm{P}} \mathrm{S}^{\mathrm{M}}\right.$ and $\left.\mathrm{Z}_{8}{ }^{* \mathrm{P}} \mathrm{S}^{\mathrm{M}}\right)$ of $(S, R, S, S)-\mathbf{3}$, in which the $\mathrm{N}$-terminal amide group forms a six- or an eight-membered ring with intramolecular H-bond with the middle amide group. According to the computations $\mathrm{Z}_{6}{ }_{\mathrm{P}} \mathrm{H}_{8}{ }^{\mathrm{P}}, \mathrm{Z}_{8}{ }^{* \mathrm{P}} \mathrm{H}_{8}{ }^{8}$, and $\mathrm{Z}_{6}{ }^{\mathrm{P}} \mathrm{S}^{\mathrm{M}}$ has considerable abundance (Table 3) at the sample evaporation temperature, at $446 \mathrm{~K}$. Although $\mathrm{Z}_{8}{ }^{* \mathrm{P}} \mathrm{S}^{\mathrm{M}}$ is predicted to be present in the gas phase at $446 \mathrm{~K}$ only in $4 \%$, keeping the conclusion in mind that for $(S, R)-\mathbf{1}$ the abundance of the $\mathrm{Z}_{8}{ }^{\mathrm{P}}$ conformer in the matrix was somewhat underestimated by the computation, $\mathrm{Z}_{8}{ }^{* \mathrm{P}} \mathrm{S}^{\mathrm{M}}$ can be present in about the same or even a bit higher concentration in the matrix than $\mathrm{Z}_{6}{ }^{\mathrm{P}} \mathrm{S}^{\mathrm{M}}$.

The amide A region proves that at least two conformers should be present in the matrix. In details, the band observed at the lowest wavenumber, at $3,303 \mathrm{~cm}^{-1}$, in the amide A region can be assigned to $\mathrm{Z}_{6}{ }^{\mathrm{P}} \mathrm{H}_{8}{ }^{\mathrm{P}}$ or/and $\mathrm{Z}_{8}{ }^{*} \mathrm{P}_{8}{ }^{\mathrm{P}}$ or/and $\mathrm{Z}_{8}{ }^{* \mathrm{P}} \mathrm{S}^{\mathrm{M}}$ (see Fig. 8; Table 6). The band observed at 3,468 $\mathrm{cm}^{-1}$ in Ar matrix can be assigned to $\mathrm{Z}_{6}{ }^{\mathrm{P}} \mathrm{H}_{8}{ }^{\mathrm{P}}$ or $\mathrm{Z}_{6}{ }^{\mathrm{P}} \mathrm{S}^{\mathrm{M}}$, or both of these two conformers. Finally, the highest frequency band, observed at $3,515 \mathrm{~cm}^{-1}$, belongs to $\mathrm{Z}_{8}{ }^{* \mathrm{P}} \mathrm{H}_{8}{ }^{\mathrm{P}}$ or/and $\mathrm{Z}_{6}{ }^{\mathrm{P}} \mathrm{S}^{\mathrm{M}}$ or/and $\mathrm{Z}_{8}{ }^{* \mathrm{P}} \mathrm{S}^{\mathrm{M}}$.

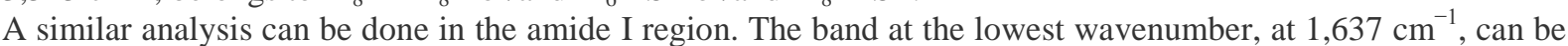
assigned to one or both of the conformers with two intramolecular $\mathrm{H}$-bond, $\mathrm{Z}_{6}{ }^{\mathrm{P}} \mathrm{H}_{8}{ }^{\mathrm{P}}$ and $\mathrm{Z}_{8}{ }^{* \mathrm{P}} \mathrm{H}_{8}{ }^{\mathrm{P}}$. The next 
band, at $1,663 \mathrm{~cm}^{-1}$, is assigned to the lowest frequency amide $\mathrm{I}$ modes $\mathrm{Z}_{6}{ }^{\mathrm{P}} \mathrm{S}^{\mathrm{M}}$ and/or $\mathrm{Z}_{8}{ }^{* \mathrm{P}} \mathrm{S}^{\mathrm{M}}$. Alternatively this band could be assigned to the middle amide $\mathrm{I}$ band of $\mathrm{Z}_{6}{ }^{\mathrm{P}} \mathrm{H}_{8}{ }^{\mathrm{P}}$ or $\mathrm{Z}_{8}{ }^{* \mathrm{P}} \mathrm{H}_{8}{ }^{\mathrm{P}}$, but this assignment is less likely, since in this case the computed wavenumbers would be higher than the observed ones, and the opposite was found in each amide I bands for the monopeptides. The highest frequency, broad band at $1,685 \mathrm{~cm}^{-1}$ and its low- and high-wavenumber $\left(1,678\right.$ and $1,694 \mathrm{~cm}^{-1}$ in $\left.\mathrm{Ar}\right)$ shoulders are assigned to the two higher frequency amide I bands of the four conformers.

Accepting the above assignments for the amide I region, it can be concluded that conformers with double and also with a single intramolecular H-bond should be present in the matrix. Although the analysis do not prove unambiguously that all the four conformers are present in the matrix, the conclusions drawn for $(S, R)$-ACBA and $(S, S)$-ACBA strongly support the presence of each of the four conformers.

\section{$(S, S, S, R)-4$}

Because of geometric reasons, in contrast to $(S, R, S, S)-\mathbf{3},(S, S, S, R)-\mathbf{4}$ has only one conformer with two intramolecular H-bond, $\mathrm{H}_{8}{ }^{\mathrm{P}} \mathrm{Z}_{8}{ }^{\mathrm{P}}$ (Fig. 5). In the other two low-energy conformers, $\mathrm{S}^{\mathrm{M}} \mathrm{Z}_{6}{ }^{\mathrm{P}}$ and $\mathrm{S}^{\mathrm{M}} \mathrm{Z}_{8}{ }^{\mathrm{P}}$, there is only a singe $\mathrm{H}$-bond. It is between the middle amide group and the C-terminal in both structures. B3LYP computations predict roughly equal abundance for these three structures at $443 \mathrm{~K}$ in the gas phase (Table 3 ).

The presence of $\mathrm{H}_{8}{ }^{\mathrm{P}} \mathrm{Z}_{8}{ }^{\mathrm{P}}$ in the matrix can unambiguously be proven based on the comparison of MI-IR and computed spectra. The lowest wavenumber band of both the amide A (at 3,253 $\mathrm{cm}^{-1}$ in Ar) and the amide I (at $1,656 \mathrm{~cm}^{-1}$ in Ar) regions can solely be assigned to $\mathrm{H}_{8}{ }^{\mathrm{P}} \mathrm{Z}_{8}{ }^{\mathrm{P}}$ (see Fig. 9; Table 7). It is also very likely that at least one of the two single intramolecular H-bonded conformers is also present, because the shoulder (at $1,706 \mathrm{~cm}^{-1}$ in $\mathrm{Ar}$ ) of the intensive amide I band (at $1,696 \mathrm{~cm}^{-1}$ in $\mathrm{Ar}$ ) very likely corresponds to the highest frequency amide I band of $\mathrm{S}^{\mathrm{M}} \mathrm{Z}_{6}{ }^{\mathrm{P}}$ and/or $\mathrm{S}^{\mathrm{M}} \mathrm{Z}_{8}{ }_{\mathrm{P}}$. (The $10 \mathrm{~cm}^{-1}$ separation of the shoulder and the main band is higher than a site splitting expected for this band.) The low-intensity band (at $1,672 \mathrm{~cm}^{-1}$ in Ar) on the shoulder of the intensive band (at $1,683 \mathrm{~cm}^{-1}$ in Ar) can almost certainly be assigned to the lowest frequency amide I band of $\mathrm{S}^{\mathrm{M}} \mathrm{Z}_{8}{ }^{\mathrm{P}}$.

From the above analysis, it can be concluded that $\mathrm{H}_{8}{ }^{\mathrm{P}} \mathrm{Z}_{8}{ }^{\mathrm{P}}$ and $\mathrm{S}^{\mathrm{M}} \mathrm{Z}_{8}{ }^{\mathrm{P}}$ is certainly present in the matrix. Although, there is no band which can solely be assigned to $\mathrm{S}^{\mathrm{M}} \mathrm{Z}_{6}{ }^{\mathrm{P}}$, based on the conclusion made for $(S, R)$ $\mathbf{1}$ and $(S, S)-\mathbf{2}$ and on the computational results, $\mathrm{S}^{\mathrm{M}} \mathrm{Z}_{6}{ }^{\mathrm{P}}$ should also be present in the matrix.

\section{Summary and conclusions}

The MI-IR spectra of ACBA mono- and dimers were recorded to analyze their conformational preferences. For the $\operatorname{cis}-(S, R)$ monomer the number of possible conformers found is consistent with our previous results. However, the conformer ratios are somewhat different. The most likely explanations of the above mismatch in relative population are (1) the shift in conformational equilibrium at higher temperatures used for sample evaporation in the MI-IR measurements and/or (2) the effect of an almost non-interacting noble gas environment with respect to solvent(s). For the trans- $(S, S)$ stereoisomer, conformational preferences match both the theoretical and NMR results; the most predominant conformer is $\mathrm{H}_{8}{ }^{\mathrm{P}}$. Once again, the conformational ratios are different, most probable for the same reasons as spelled out above.

Structural results obtained for dimers, $(S, R, S, S)-\mathbf{3}$ and $(S, S, S, R)-\mathbf{4}$, while generally agree with the ${ }^{1} \mathrm{H}-\mathrm{NMR}$ data presented earlier (Gorrea et al. 2012), also show some minor differences. It is to be seen that the protective groups are different here than was in our previous work ( $N$-Ac instead of $N$-Boc), which could account for the slight differences in populations. For $(S, R, S, S)-\mathbf{3}$ four conformers were found including the $\mathrm{Z}_{6}{ }^{\mathrm{P}} \mathrm{H}_{8}{ }^{\mathrm{P}}$ novel foldamer which links two different secondary structural element via a bifurcated H-bond. While its presence was hypothesized based on NMR and computational data, its existence is now fully confirmed and with this a new structural building block is introduced.

As the NH group cannot form a similar bifurcated H-bond in $(S, S, S, R)-\mathbf{4}$ we do not expect the appearance of such foldamer. Although, due to congestion, the complete analysis of the spectra of $(S, R, S, S)-\mathbf{3}$ and $(S, S, S, R)$ 4 model systems could not be performed, nevertheless this is the first time that a protected dipeptide (i.e. triamide) was deposited in a noble gas matrix, and its MI-IR spectra, at least partially, was analyzed. In case of future studies the problem arisen by congestion can be overcome and the analysis can be supported by inducing conformational conversion by selective narrow band IR (or UV) laser irradiation. This combined matrix isolation and laser irradiation technique has already been shown to be very useful to investigate tautomers and conformers of small biomolecules in the matrix, e.g. cytosine (Lapinski et al. 2010,2011) glycine (Bazsó et al. 2012a,b), and alanine (Bazsó et al. 2013; Nunes et al. 2013). 


\section{Acknowledgments}

This work was funded by the Hungarian Scientific Research Fund (OTKA K75877, K72973, NK101072), the Spanish Ministerio de Ciencia e Innovación (CTQ2010-15408/BQU) and the Generalitat de Catalunya, Spain (2009SGR-733). The European Union and the European Social Fund have provided financial support to the project under the grant no. TAMOP 4.2.1./B-09/KMR-2010-0003 and COST Action CM0803.

\section{References}

Baker J, Jarzecki AA, Pulay P (1998) Direct scaling of primitive valence force constants: an alternative approach to scaled quantum mechanical force fields. J Phys Chem A 102(8):1412-1424CrossRef

Baker J, Wolinski K, Malagoli M, Kinghorn D, Wolinski P, Magyarfalvi G, Saebo S, Janowski T, Pulay P (2009) Quantum chemistry in parallel with PQS. J Comput Chem 30(2):317-335

Bazsó G, Magyarfalvi G, Tarczay G (2012a) Near-infrared laser induced conformational change and UV laser photolysis of glycine in low-temperature matrices: observation of a short-lived conformer. J Mol Struct 1025:3342CrossRef

Bazsó G, Magyarfalvi G, Tarczay G (2012b) Tunneling lifetime of the ttc/VIp conformer of glycine in lowtemperature matrices. J Phys Chem A 116(43):10539-10547PubMedCrossRef

Bazsó G, Najbauer EE, Magyarfalvi G, Tarczay G (2013) Near-infrared laser induced conformational change of alanine in low-temperature matrixes and the tunneling lifetime of its conformer VI. J Phys Chem A 117(9):1952-1962

Becke AD (1993) Density-functional thermochemistry. III. The role of exact exchange. J Chem Phys 98(7):5648-5652CrossRef

Beke T, Somlai C, Perczel A (2006) Toward a rational design of $\beta$-peptide structures. J Comput Chem 27(1):2038PubMedCrossRef

Beke T, Somlai C, Magyarfalvi G, Perczel A, Tarczay G (2009) Chiral and achiral fundamental conformational building units of $\beta$-peptides: a matrix isolation conformational study on Ac- $\beta$-HGly-NHMe and Ac- $\beta$-HAlaNHMe. J Phys Chem B 113(22):7918-7926PubMedCrossRef

Binkley JS, Pople JA, Hehre WJ (1980) Self-consistent molecular orbital methods. 21. Small split-valence basis sets for first-row elements. J Am Chem Soc 102(3):939-947CrossRef

Boeckx B, Maes G (2012a) Potential energy surface and matrix isolation FT-IR study of isoleucine. J Phys Chem A 116(12):3247-3258PubMedCrossRef

Boeckx B, Maes G (2012b) The conformational behavior and H-bond structure of asparagine: a theoretical and experimental matrix-isolation FT-IR study. Biophys Chem 165-166:62-73PubMedCrossRef

Boeckx B, Maes G (2012c) Experimental and theoretical observation of different intramolecular H-bonds in lysine conformations. J Phys Chem B 116(41):12441-12449PubMedCrossRef 
Boeckx B, Maes G (2012d) Comparison of the conformational behavior of amino acids and N-acetylated amino acids: a theoretical and matrix-isolation FT-IR study of N-acetylglycine. J Phys Chem A 116(8):19561965PubMedCrossRef

Boeckx B, Maes G (2012e) Estimation of the rotamerization constants of different conformations of Nacetylalanine: a theoretical and matrix-isolation FT-IR study. Spectrochim Acta A 86:366-374CrossRef

Boeckx B, Ramaekers R, Maes G (2010) A theoretical and matrix-isolation FT-IR investigation of the conformational landscape of N-acetylcysteine. J Mol Spectrosc 261(2):73-81CrossRef

Boeckx B, Ramaekers R, Maes G (2011) The influence of the peptide bond on the conformation of amino acids: a theoretical and FT-IR matrix-isolation study of N-acetylproline. Biophys Chem 159(2-3):247256PubMedCrossRef

Dobrowolski JC, Jamróz MH, Kołos R, Rode JE, Sadlej J (2007) Theoretical prediction and the First IR matrix observation of several L-cysteine molecule conformers. Chem Phys Chem 8(7):1085-1094PubMedCrossRef

Dobrowolski JC, Jamróz HM, Kolos R, Rode JE, Sadlej J (2008) IR low-temperature matrix and ab initio study on $\beta$-alanine conformers. Chem Phys Chem 9(14):2042-2051PubMedCrossRef

Fábri C, Szidarovszky T, Magyarfalvi G, Tarczay G (2011) Gas-phase and Ar-matrix SQM scaling factors for various DFT functionals with basis sets including polarization and diffuse functions. J Phys Chem A 115(18):4640-4649PubMedCrossRef

Fernandes C, Faure S, Pereira E, Théry V, Declerck V, Guillot R, Aitken DJ (2010) 12-helix folding of cyclobutane $\beta$-amino acid oligomers. Org Lett 12(16):3606-3609PubMedCrossRef

Frisch MJ, Trucks GW, Schlegel HB, Scuseria GE, Robb MA, Cheeseman JR, Scalmani G, Barone V, Mennucci B, Petersson GA, Nakatsuji H, Caricato M, Li X, Hratchian HP, Izmaylov AF, Bloino J, Zheng G, Sonnenberg JL, Hada M, Ehara M, Toyota K, Fukuda R, Hasegawa J, Ishida M, Nakajima T, Honda Y, Kitao O, Nakai H, Vreven T, Montgomery Jr. JA, Peralta JE, Ogliaro F, Bearpark M, Heyd JJ, Brothers E, Kudin KN, Staroverov VN, Kobayashi R, Normand J, Raghavachari K, Rendell A, Burant JC, Iyengar SS, Tomasi J, Cossi M, Rega N, Millam JM, Klene M, Knox JE, Cross JB, Bakken V, Adamo C, Jaramillo J, Gomperts R, Stratmann RE, Yazyev O, Austin AJ, Cammi R, Pomelli C, Ochterski JW, Martin RL, Morokuma K, Zakrzewski VG, Voth GA, Salvador P, Dannenberg JJ, Dapprich S, Daniels AD, Farkas Ö, Foresman JB, Ortiz JV, Cioslowski J, Fox DJ (2009) Gaussian 09, Revision A.1. Gaussian Inc, Wallingford, CT

Góbi S, Knapp K, Vass E, Majer Z, Magyarfalvi G, Hollósi M, Tarczay G (2010) Is $\beta$-homo-proline a pseudo- $\gamma$ turn forming element of $\beta$-peptides? An IR and VCD spectroscopic study on Ac- $\beta$-HPro-NHMe in cryogenic matrices and solutions. Phys Chem Chem Phys 12(41):13603-13615PubMedCrossRef

Gorrea E, Pohl G, Nolis P, Celis S, Burusco KK, Branchadell V, Perczel A, Ortuño RM (2012) Secondary structure of short $\beta$-peptides as the chiral expression of monomeric building units: a rational and predictive model. J Org Chem 77(21):9795-9806PubMedCrossRef

Grenie Y, Garrigou-Lagrange C (1972) Infrared spectra of glycine isotopic species isolated in an argon or nitrogen matrix. J Mol Spectrosc 41(2):240-246CrossRef 
Grenie Y, Lassegues JC, Garrigou-Lagrange C (1970) Infrared spectrum of matrix-isolated glycine. J Chem Phys 53(7):2980-2982CrossRef

Grenie Y, Avignon M, Garrigou-Lagrange C (1975) Molecular structure study of dipeptides isolated in an argon matrix by infrared spectroscopy. J Mol Struct 24(2):293-307CrossRef

Halgren TA (1996) Merck molecular force field. I. Basis, form, scope, parameterization, and performance of MMFF94. J Comput Chem 17(5-6):490-519CrossRef

Hehre WJ, Ditchfield R, Pople JA (1972) Self-consistent molecular orbital methods. XII. Further extensions of gaussian-type basis sets for use in molecular orbital studies of organic molecules. J Chem Phys 56(5):22572261CrossRef

Ivanov AYu, Plokhotnichenko AM, Izvekov V, Sheina GG, Blagoi YuP (1997) FTIR investigation of the effect of matrices ( $\mathrm{Kr}, \mathrm{Ar}, \mathrm{Ne})$ on the UV-induced isomerization of the monomeric links of biopolymers. J Mol Struct 408-409:459-462CrossRef

Ivanov AYu, Sheina G, Blagoi YuP (1999) FTIR spectroscopic study of the UV-induced rotamerization of glycine in the low temperature matrices (Kr, Ar, Ne). Spectrochim Acta Part A 55(1):219-228

Jarmelo S, Lapinski L, Nowak MJ, Carey PR, Fausto R (2005) Preferred conformers and photochemical $(\lambda>200 \mathrm{~nm})$ reactivity of serine and 3,3-dideutero-serine in the neutral form. J Phys Chem A 109(25):56895707PubMedCrossRef

Jarmelo S, Reva ID, Rozenberg M, Carey PR, Fausto R (2006) Low-temperature infrared spectra and hydrogen bonding in polycrystalline dl-serine and deuterated derivatives. Vib Spectr 41(1):73-82CrossRef

Kaczor A, Reva ID, Proniewicz LM, Fausto R (2006) Importance of entropy in the conformational equilibrium of phenylalanine: a matrix-isolation infrared spectroscopy and density functional theory study. J Phys Chem A 110(7):2360-2370PubMedCrossRef

Kaczor A, Reva ID, Proniewicz LM, Fausto R (2007) Matrix-isolated monomeric tryptophan: electrostatic interactions as nontrivial factors stabilizing conformers. J Phys Chem A 111(15):2957-2965PubMedCrossRef

Lambie B, Ramaekers R, Maes G (2003) On the contribution of intramolecular H-bonding entropy to the conformational stability of alanine conformations. Spectrochim Acta A 59(6):1387-1397CrossRef

Lambie B, Ramaekers R, Maes G (2004) Conformational behavior of serine: an experimental matrix-isolation FT-IR and theoretical DFT(B3LYP)/6-31++G** study. J Phys Chem A 108(47):10426-10433CrossRef

Lapinski L, Nowak MJ, Reva ID, Rostkowska H, Fausto R (2010) NIR-laser-induced selective rotamerization of hydroxy conformers of cytosine. Phys Chem Chem Phys 12(33):9615-9618PubMedCrossRef

Lapinski L, Reva I, Nowak MJ, Fausto R (2011) Five isomers of monomeric cytosine and their interconversions induced by tunable UV laser light. Phys Chem Chem Phys 13(20):9676-9684PubMedCrossRef

Lee C, Yang W, Parr RG (1998) Development of the colle-salvetti correlation-energy formula into a functional of the electron density. Phys Rev B 37(2):785-789CrossRef 
Mohamadi F, Richards NG, Guida WC, Liskamp R, Lipton M, Caufield C, Chang G, Hendrickson T, Still WC, MacroModel 7.0 (1990) Macromodel - an integrated software system for modeling organic and bioorganic molecules using molecular mechanics. J Comput Chem 11(4):440-467

Nunes CM, Lapinski L, Fausto R, Reva I (2013) Near-IR laser generation of a high-energy conformer of Lalanine and the mechanism of its decay in a low-temperature nitrogen matrix. J Chem Phys 138(12):125101PubMedCrossRef

Pohl G, Perczel A, Vass E, Magyarfalvi G, Tarczay G (2007) A matrix isolation study on Ac-Gly-NHMe and Ac-l-Ala-NHMe, the simplest chiral and achiral building blocks of peptides and proteins. Phys Chem Chem Phys 9(33):4698-4708PubMedCrossRef

Pohl G, Perczel A, Vass E, Magyarfalvi G, Tarczay G (2008) A matrix isolation study on Ac-1-Pro- $\mathrm{NH}_{2}$ : a frequent structural element of $\beta$ - and $\gamma$-turns of peptides and proteins. Tetrahedron 64(9):2126-2133CrossRef

Pulay P, Fogarasi G, Pongor G, Boggs JE, Vargha A (1983) Combination of theoretical ab initio and experimental information to obtain reliable harmonic force constants. Scaled quantum mechanical (QM) force fields for glyoxal, acrolein, butadiene, formaldehyde, and ethylene. J Am Chem Soc 105(24):70377047CrossRef

Ramaekers R, Pajak J, Rospenk M, Maes G (2005) Matrix-isolation FT-IR spectroscopic study and theoretical DFT(B3LYP)/6-31++G** calculations of the vibrational and conformational properties of tyrosine. Spectrochim Acta Part A 61(7):1347-1356CrossRef

Reva ID, Plokhotnichenko AM, Stepanian SG, Ivanov AYu, Radchenko ED, Sheina GG, Blagoi YP (1995) The rotamerization of conformers of glycine isolated in inert gas matrices. An infrared spectroscopic study. Chem Phys Lett 232(1-2):141-148 (1995) Erratum. Chem Phys Lett 235(5-6):617-617CrossRef

Reva ID, Stepanian SG, Plokhotnichenko A, Radchenko ED, Sheina G, Blagoi YuP (1994) Infrared matrix isolation studies of amino acids. Molecular structure of proline. J Mol Struct 318:1-13CrossRef

Rosado MTS, Duarte MLRS, Fausto R (1997) Vibrational spectra (FT-IR, Raman and MI-IR) of $\alpha$ - and $\beta$ alanine. J Mol Struct 410-411:343-348

Sheina GG, Radchenko ED, Ivanov AY, Stepanian SG, Blagoi YP (1988) Oscillating spectra of leucine. Zh Fiz Khim 62:985-990

Stepanian SG, Reva ID, Radchenko ED, Rosado MTS, Duarte MLTS, Fausto R, Adamowicz L (1998a) Matrixisolation infrared and theoretical studies of the glycine conformers. J Phys Chem A 102(6):1041-1054CrossRef Stepanian SG, Reva ID, Radchenko ED, Adamowicz L (1998b) Conformational behavior of $\alpha$-alanine. Matrixisolation infrared and theoretical DFT and ab initio study. J Phys Chem A 102(24):4623-4629CrossRef Stepanian SG, Reva ID, Radchenko ED, Adamowicz L (1999) Combined matrix-isolation infrared and theoretical DFT and ab initio study of the nonionized valine conformers. J Phys Chem A 103(22):44044412CrossRef

Stepanian SG, Reva ID, Radchenko ED, Adamowicz L (2001) Conformers of nonionized proline. Matrixisolation infrared and post-hartree-fock ab initio study. J Phys Chem A 105(47):10664-10672CrossRef 
Tarczay G, Góbi S, Vass E, Magyarfalvi G (2009) Model peptide-water complexes in Ar matrix: complexation induced conformation change and chirality transfer. Vib Spectrosc 50(1):21-28CrossRef

Torres E, Gorrea E, Da Silva E, Nolis P, Branchadell V, Ortuño RM (2009) Prevalence of eight-membered hydrogen-bonded rings in some bis(cyclobutane) $\beta$-dipeptides including residues with trans stereochemistry. Org Lett 11(11):2301-2304PubMedCrossRef

Torres E, Gorrea E, Burusco KK, Da Silva E, Nolis P, Rúa F, Boussert S, Díez-Pérez I, Dannenberg S, Izquierdo S, Giralt E, Jaime C, Branchadell V, Ortuño RM (2010) Folding and self-assembling with beta-oligomers based on (1R,2S)-2-aminocyclobutane-1-carboxylic acid. Org Biomol Chem 8(3):564-575PubMedCrossRef

Wierzejewska M, Olbert-Majkut A (2009) Conformational behavior of the simplest dipeptide: formylglycine. Quantum chemical and matrix isolation FTIR study. Chem Phys Lett 476(4-6):287-292CrossRef 


\section{Figures and Tables:}

Figures:<smiles>CNC(=O)[C@@H]1CC[C@H]1NC(C)=O</smiles>

$(S, R)-1$<smiles>CNC(=O)[C@@H]1CC[C@H]1NC(C)=O</smiles>

(S,S)-2

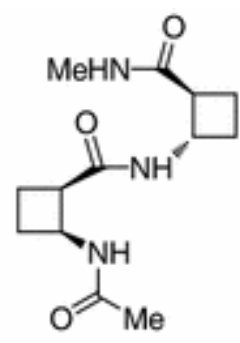

$(S, R, S, S)-3$

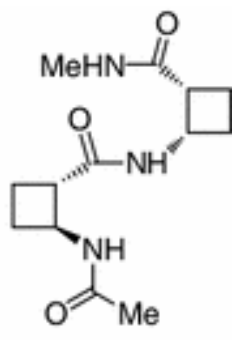

$(S, S, S, R)-4$

Fig. 1

Molecules considered in this work<smiles>CCCCOC(=O)N[C@H]1CC[C@H]1C(=O)N[C@H]1CC[C@H]1C(=O)OC</smiles>

5
$(S, R, S, S)-3$

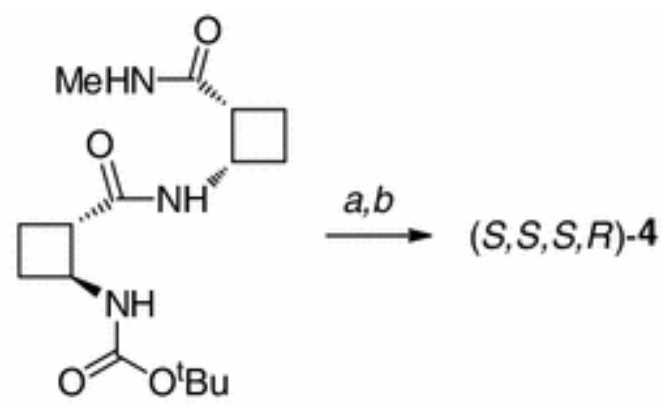

6

Scheme 1

Reagents, conditions, yields: a TFA $\mathrm{Et}_{3} \mathrm{SiH}, \mathrm{rt}, 2 \mathrm{~h}$, quantitative. b $\mathrm{Ac}_{2} \mathrm{O}$, Dmap, $\mathrm{Et}_{3} \mathrm{~N}$, rt, overnight, 63$81 \%$. c $0.25 \mathrm{M} \mathrm{NaOH}, \mathrm{THF}-\mathrm{H}_{2} \mathrm{O}, 0{ }^{\circ} \mathrm{C}, 2 \mathrm{~h}, 99 \%$. d $2.0 \mathrm{M} \mathrm{MeNH}_{2}$ in THF, DIPEA, FDPP, DMF, rt, overnight, $84 \%$

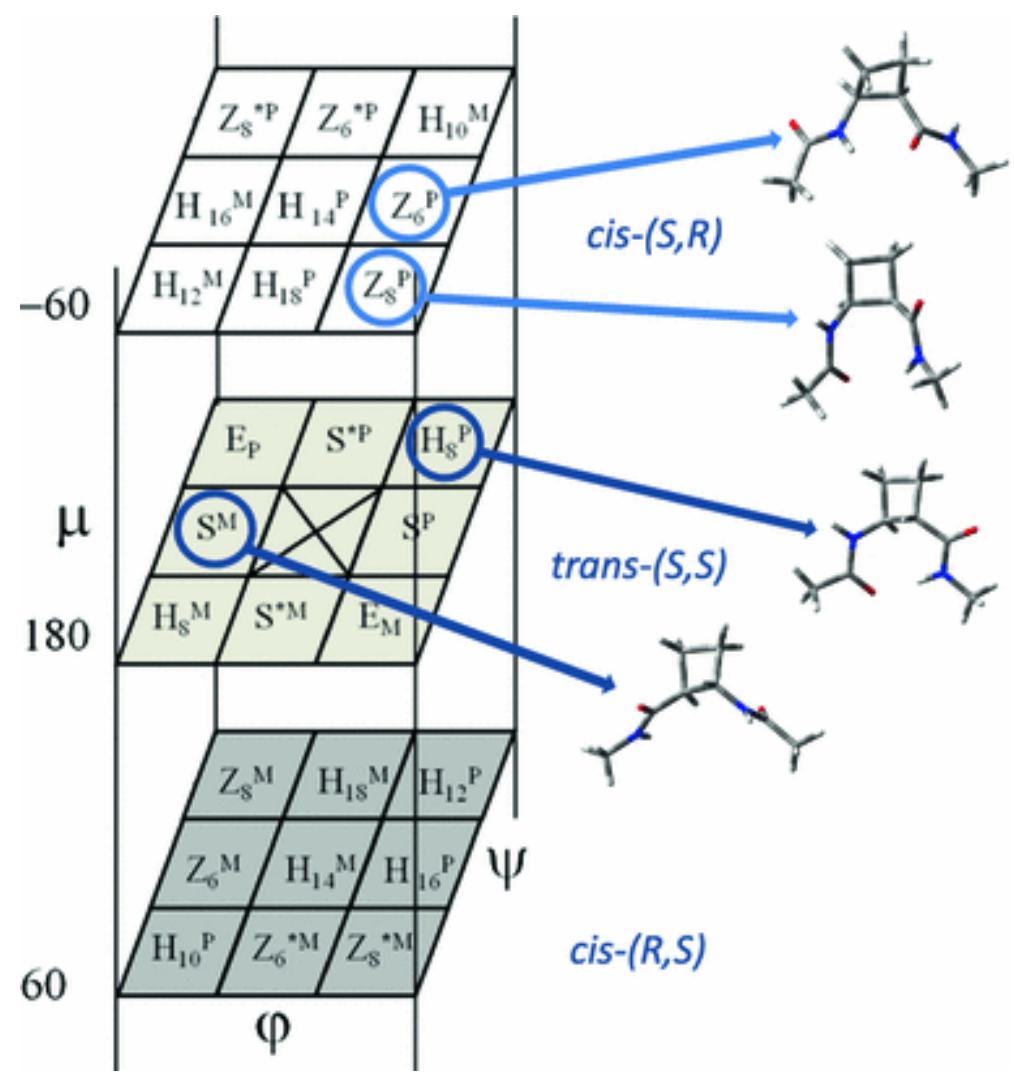


Fig. 2

Selected cross-sections of the Ramachandran-type-cube of the cis- $(S, R)$, the cis- $(R, S)$, and the trans- $(S, S)$ monomeric building units derived from 2-aminocyclobutane-1-carboxylic acid: $\mathrm{S}$ (spiral) and E (elongated) refer to additional possible conformations

Initial geometries were obtained by a conformational search using the MMFF force field (Halgren 1996) implemented in the Macromodel 7.0 program (Mohamadi et al. 1990). These structures were optimized first at the HF/3-21G (Binkley et al. 1980), and finally at the B3LYP (Becke 1993; Lee et al. 1998)/6-31++G(d,p) (Hehre et al. 1972) level of theory. The optimizations were followed by second derivative calculations to determine whether the obtained stationary points correspond to minima. The optimized structures are shown in Figs. 3, 4, 5, the most important dihedral angles of the optimized structures are collected in Tables 1, 2.
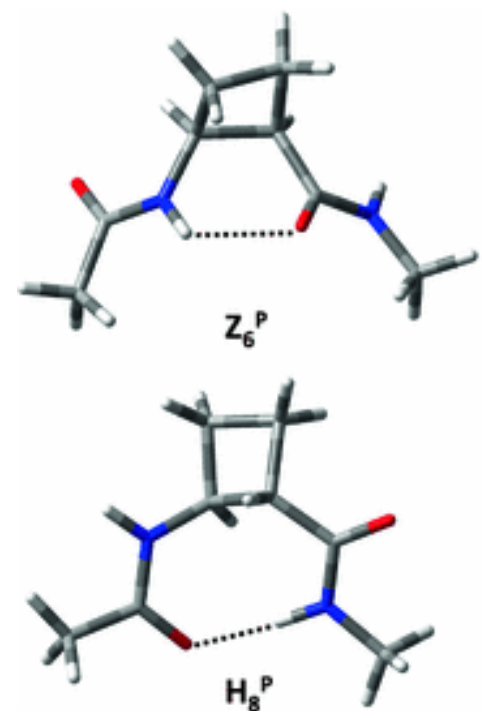

SR

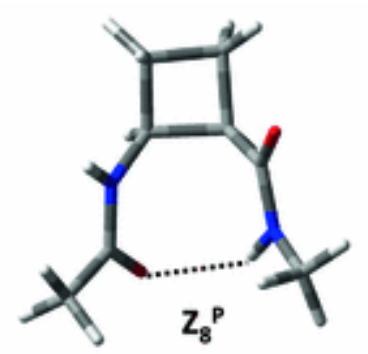

SS

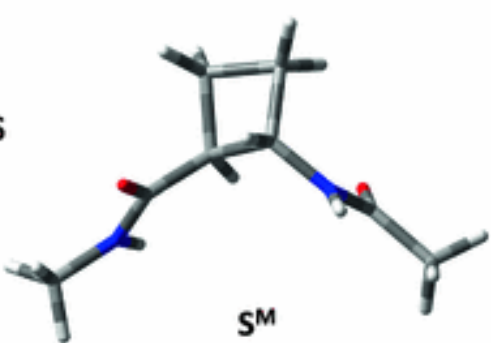

Fig. 3

Structures of the most abundant conformers of $(S, R)-\mathbf{1}$ and $(S, S)-\mathbf{2}$ as obtained from geometry optimization at the B3LYP/6-31++G(d,p) level of theory
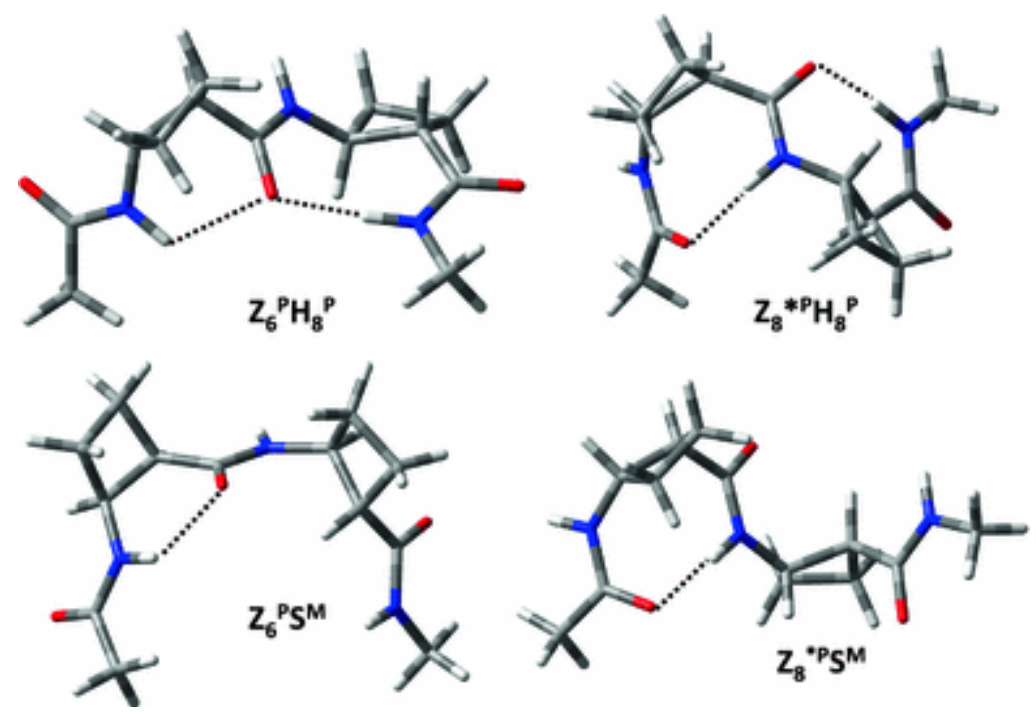

Fig. 4

Structures of the most abundant conformers of $(S, R, S, S)-\mathbf{3}$ as obtained from geometry optimization at the B3LYP/6-31++G(d,p) level of theory 

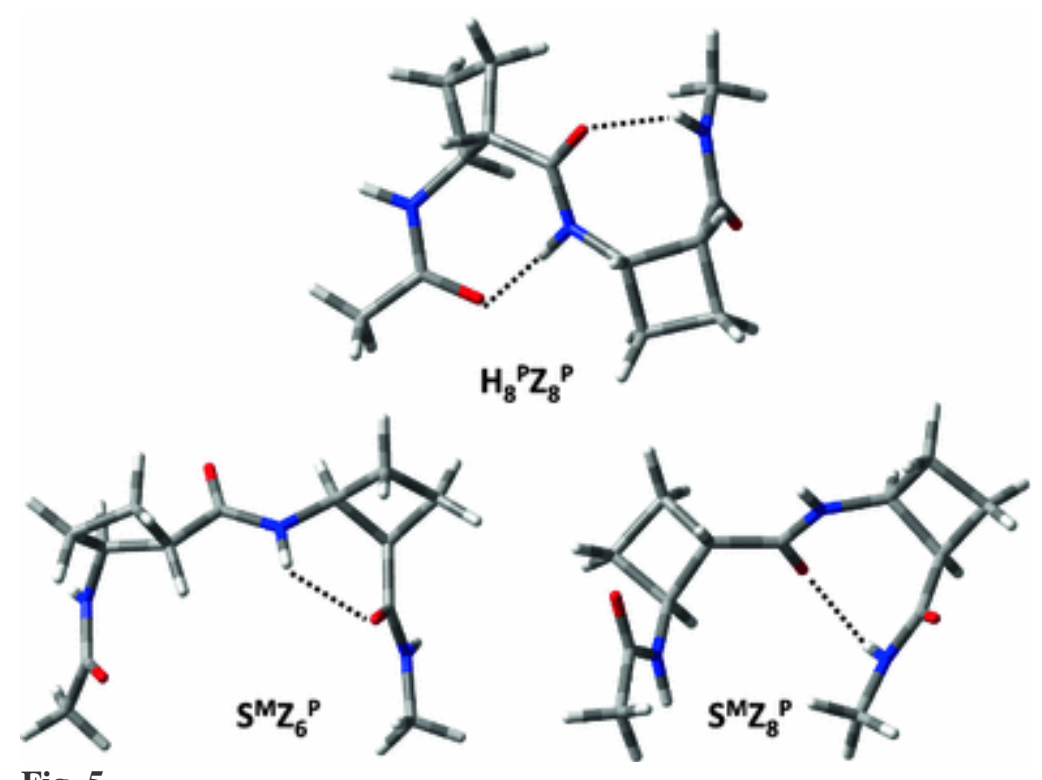

Fig. 5

Structures of the most abundant conformers of $(S, S, S, R)-\mathbf{4}$ as obtained from geometry optimization at the B3LYP/6-31++G(d,p) level of theory
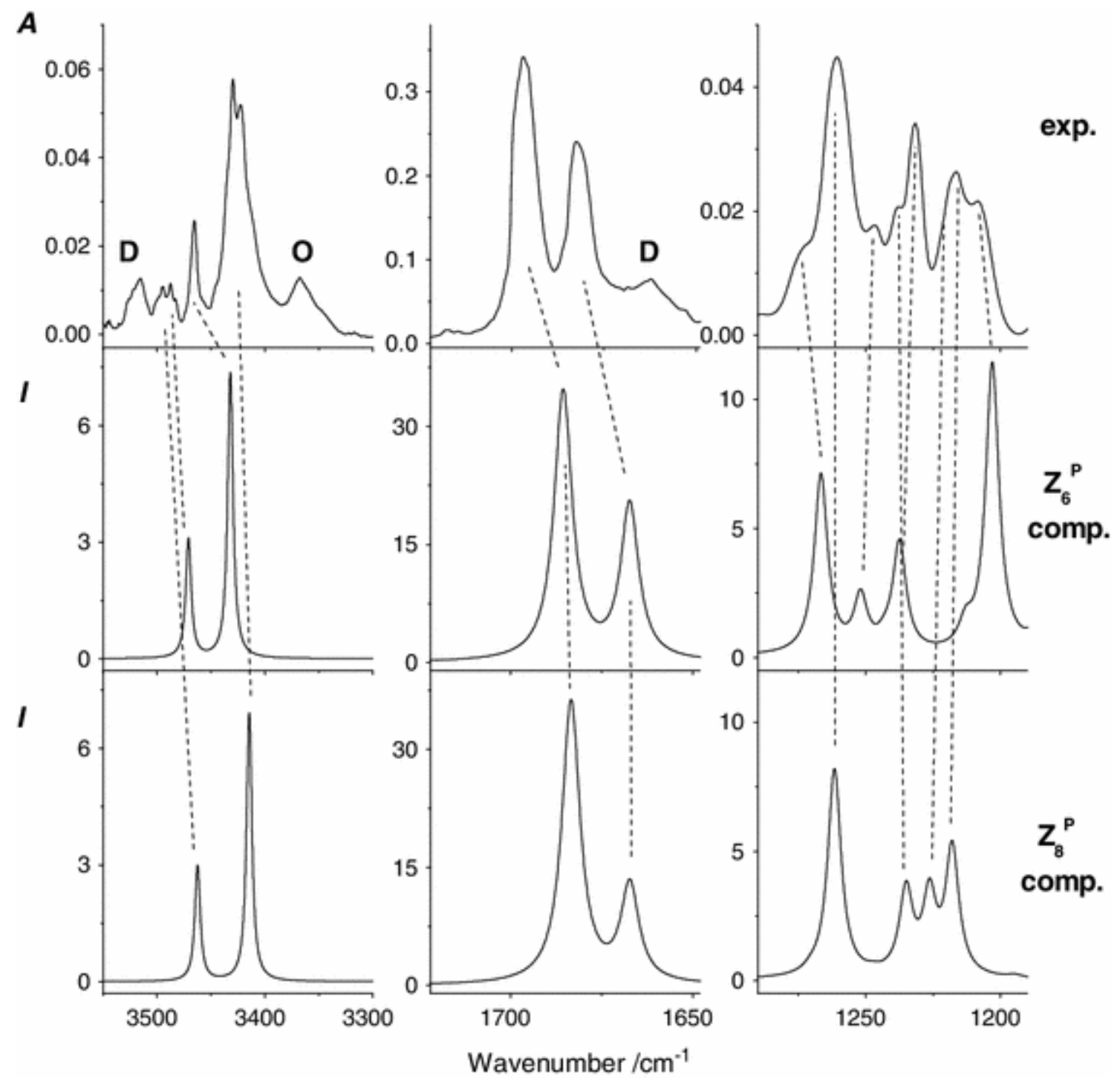
Fig. 6

Experimental MI-IR (top) spectrum of $(S, R)-\mathbf{1}$ and the computed IR spectra (SQM B3LYP//6-31++G(d,p)) of $(S, R)-\mathbf{1}$ conformers in the amide A (left), amide I (middle) and in the $1,190-1,290 \mathrm{~cm}^{-1}$ spectral region (right). $O$ overtone, $D$ dimer (or complexes with traces of water). Owing to site splittings, presence of overtone bands, and Fermi resonances the assignments are tentative in the amide $\mathrm{A}(\mathrm{N}-\mathrm{H}$ stretching) region

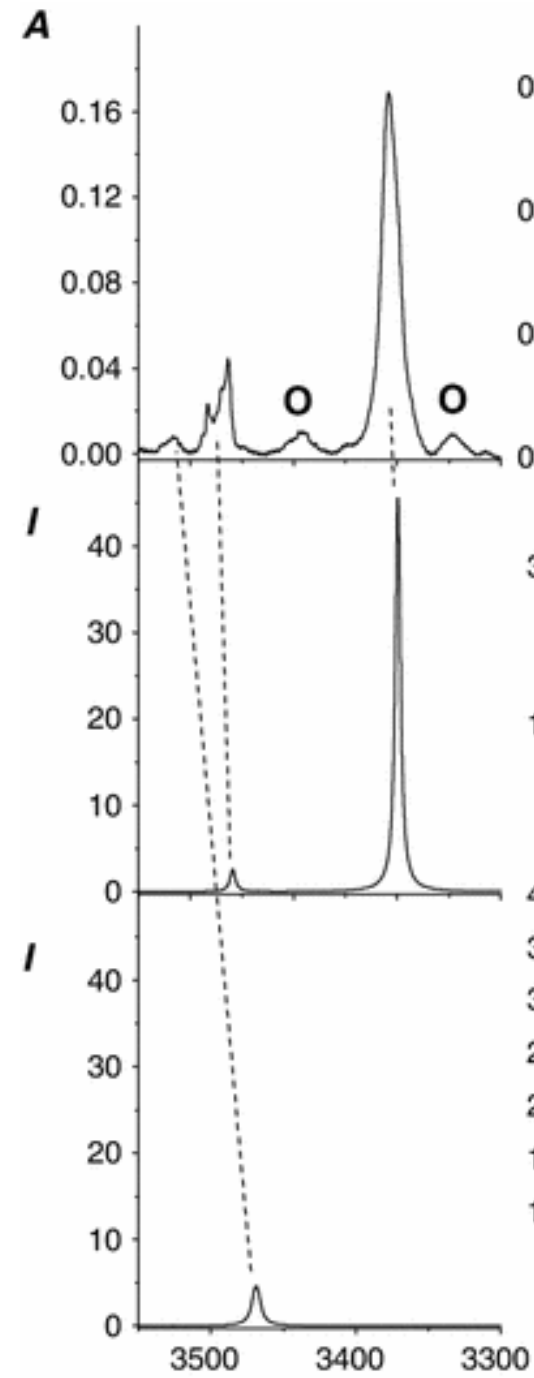

Fig. 7

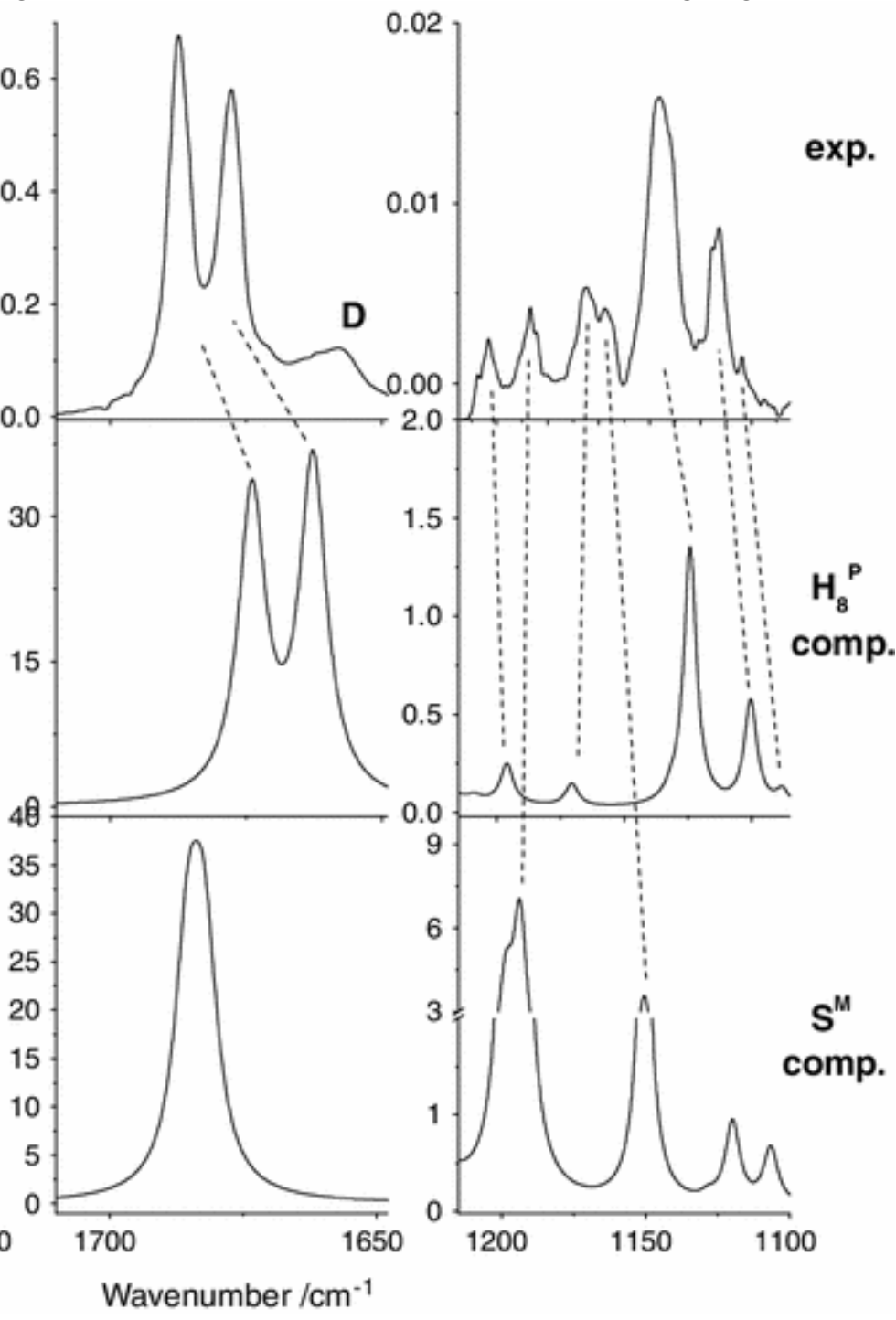

Experimental MI-IR (top) spectrum of $(S, S)-2$ and the computed IR spectra (SQM B3LYP//6-31++G(d,p)) of $(S, S)-2$ conformers in the amide A (left), amide I (middle) and in the $1,100-1,215 \mathrm{~cm}^{-1}$ spectral region (right). $O$ overtone, $D$ dimer. Owing to site splittings, presence of overtone bands, and Fermi resonances the assignments are tentative in the amide $\mathrm{A}\left(\mathrm{N}-\mathrm{H}\right.$ stretching) region. Note that the intensity scale of $\mathrm{H}_{8} \mathrm{P}^{\mathrm{and}}$ $\mathrm{S}^{\mathrm{M}}$ conformers in the $1,100-1,215 \mathrm{~cm}^{-1}$ spectral region is different 

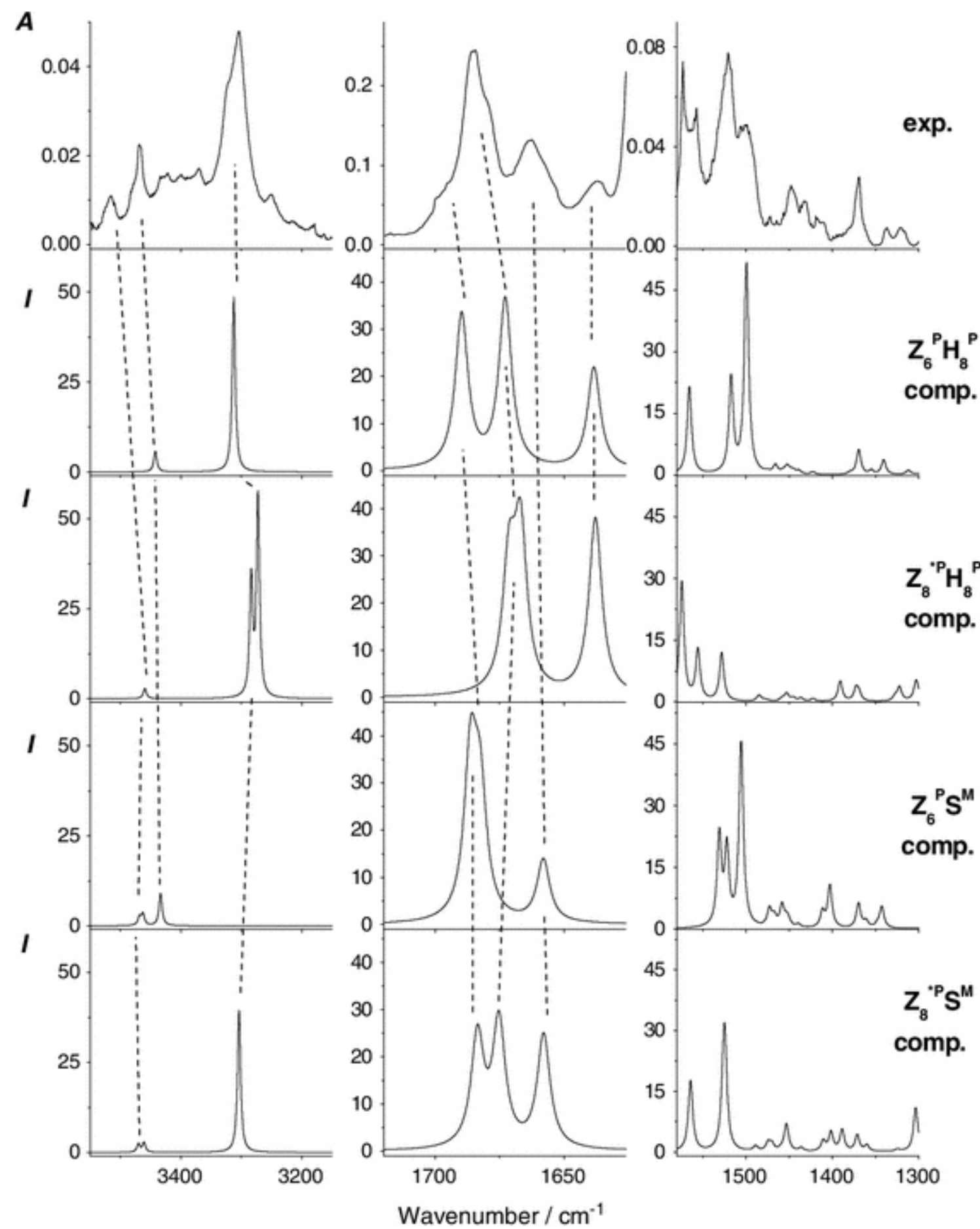

Fig. 8

Experimental MI-IR (top) spectrum of $(S, R, S, S)-3$ and the computed IR spectra (SQM B3LYP//6-31++G(d,p)) of $(S, R, S, S)-3$ conformers in the amide A (left), amide I (middle) and in the 1,300-1,580 $\mathrm{cm}^{-1}$ spectral region (right) 

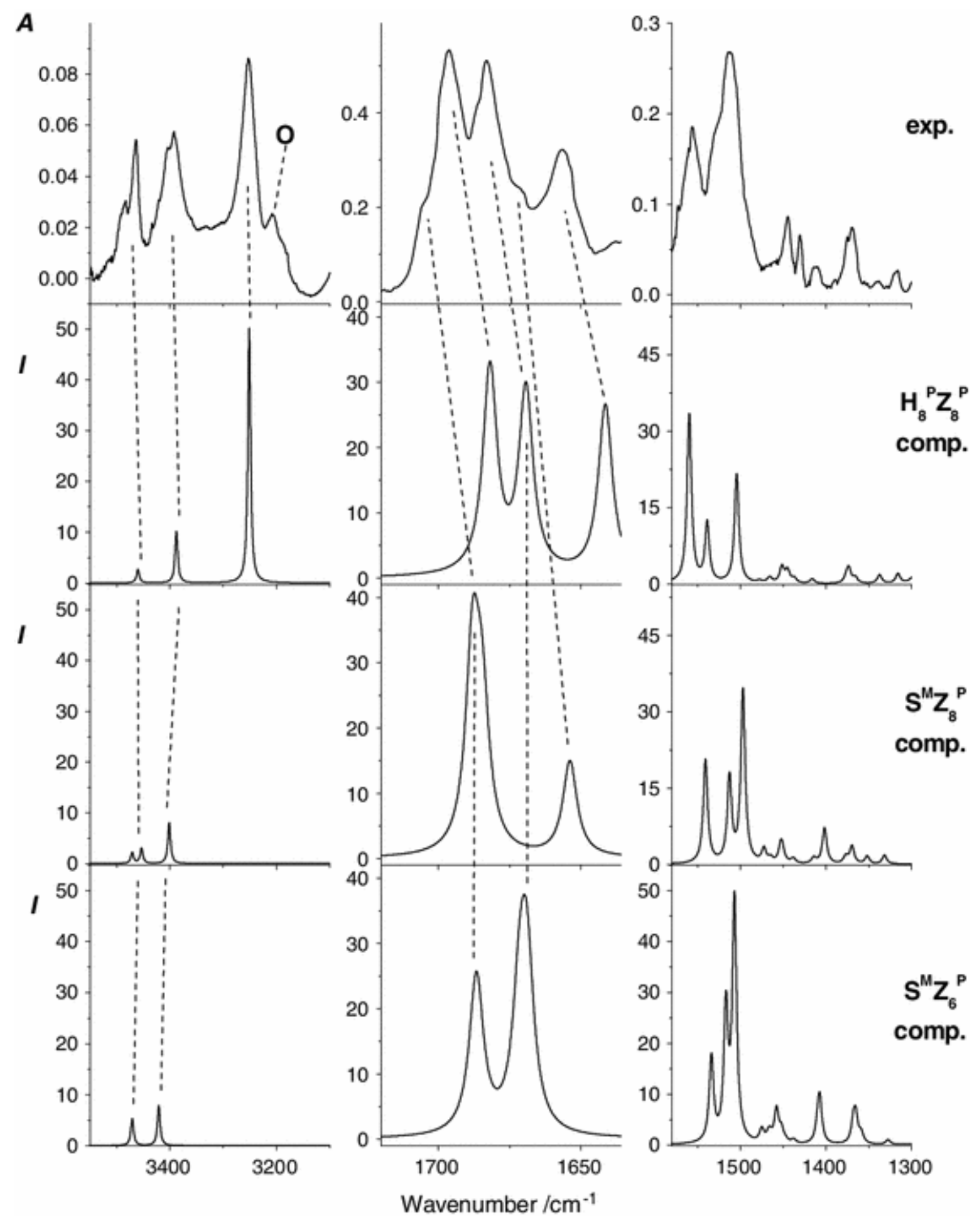

Fig. 9

Experimental MI-IR (top) spectrum of $(S, S, S, R)-\mathbf{4}$ and the computed IR spectra (SQM B3LYP/6-31++G(d,p)) of $(S, S, S, R)-\mathbf{4}$ conformers in the amide A (left), amide I (middle) and in the $1,300-1,580 \mathrm{~cm}^{-1}$ spectral region (right). $O$ overtone band

\section{Tables:}

Table 1

Computed (B3LYP/6-31++G(d,p)) dihedral angles of the conformers of $(S, R)-\mathbf{1}$ and $(S, S)-\mathbf{2}$ 


\begin{tabular}{|l|l|l|l|l|}
\hline \multicolumn{3}{|c|}{ Dihedral angles } & \multicolumn{2}{l|}{ Classification } \\
\hline $\boldsymbol{\varphi}$ & $\boldsymbol{\mu}$ & $\boldsymbol{\psi}$ & Gorrea et al. (2012) & Present work \\
\hline$(S, R)-\mathbf{1}$ & & & \\
\hline-73 & -21 & 89 & $\mathrm{Z}_{8}{ }^{\mathrm{P}}$ & $\mathrm{Z}_{8}{ }^{\mathrm{P}}$ \\
\hline-123 & -26 & 147 & $\mathrm{Z}_{6}{ }^{\mathrm{P}}$ & $\mathrm{Z}_{6}{ }^{\mathrm{P}}$ \\
\hline$(S, S)-2$ & & & & \\
\hline-88 & 101 & -31 & $\mathrm{H}_{8}{ }^{\mathrm{P}}$ & $\mathrm{H}_{8}{ }^{\mathrm{P}}$ \\
\hline 53 & 94 & -143 & $\mathrm{Z}_{6}{ }^{\mathrm{M}}$ & $\mathrm{S}^{\mathrm{M}}$ \\
\hline
\end{tabular}

Table 2

Computed (B3LYP/6-31++G(d,p)) dihedral angles of the conformers of $(S, R, S, S)-\mathbf{3}$ and $(S, S, S, R)-\mathbf{4}$

\section{Dihedral angles}

\begin{tabular}{|c|c|c|c|c|c|c|}
\hline$\varphi 1$ & $\boldsymbol{\mu} \mathbf{1}$ & $\psi 1$ & $\varphi 2$ & $\boldsymbol{\mu} 2$ & $\psi 2$ & $\begin{array}{l}\text { Gorrea et al. } \\
(2012)\end{array}$ \\
\hline
\end{tabular}

$(S, R, S, S)-3$

\begin{tabular}{|l|l|l|l|l|l|l|l|}
\hline 85 & -27 & -41 & -85 & 104 & -33 & $\mathrm{Z}_{8}{ }^{\mathrm{P}} \mathrm{H}_{8}{ }^{\mathrm{P}}$ & $\mathrm{Z}_{8}{ }^{* \mathrm{P}} \mathrm{H}_{8}{ }^{\mathrm{P}}$ \\
\hline-128 & -28 & 156 & 56 & 96 & -143 & $\mathrm{Z}_{6}{ }^{\mathrm{P}} \mathrm{Z}_{6}{ }^{\mathrm{P}}$ & $\mathrm{Z}_{6}{ }^{\mathrm{P}} \mathrm{S}^{\mathrm{M}}$ \\
\hline-122 & -27 & 146 & -87 & 104 & -35 & $\mathrm{Z}_{6}{ }^{\mathrm{P}} \mathrm{H}_{8}{ }^{\mathrm{P}}$ & $\mathrm{Z}_{6}{ }^{\mathrm{P}} \mathrm{H}_{8}{ }^{\mathrm{P}}$ \\
\hline 83 & -21 & -47 & 55 & 94 & -131 & $\mathrm{Z}_{8}{ }^{\mathrm{P}} \mathrm{Z}_{6}{ }^{\mathrm{P}}$ & $\mathrm{Z}_{8}{ }^{* \mathrm{P}} \mathrm{S}^{\mathrm{M}}$ \\
\hline$(S, S, S, R)-4$ & & & & & & \\
\hline-87 & 101 & -29 & -72 & -21 & 85 & $\mathrm{H}_{8}{ }^{\mathrm{P}} \mathrm{Z}_{8}{ }^{\mathrm{P}}$ & $\mathrm{H}_{8}{ }^{\mathrm{P}} \mathrm{Z}_{8}{ }^{\mathrm{P}}$ \\
\hline 54 & 96 & -153 & -75 & -21 & 88 & $\mathrm{Z}_{6}{ }^{\mathrm{M}} \mathrm{Z}_{8}{ }^{\mathrm{P}}$ & $\mathrm{S}^{\mathrm{M}} \mathrm{Z}_{8}{ }^{\mathrm{P}}$ \\
\hline 55 & 95 & -159 & -131 & -26 & 148 & $\mathrm{Z}_{6}{ }^{\mathrm{M}} \mathrm{Z}_{6}{ }^{\mathrm{P}}$ & $\mathrm{S}^{\mathrm{M}} \mathrm{Z}_{6}{ }^{\mathrm{P}}$ \\
\hline
\end{tabular}

Harmonic vibrational frequencies and intensities were calculated at the B3LYP/6-31++G(d,p) level of theory using the scaled quantum mechanical (SQM) force field scheme (Pulay et al.1983; Baker et al. 1998) with scaling factors determined by Fábri et al. (2011). All the quantum chemical calculations were performed by the PQS (Parallel Quantum Solutions) 3.2 (Baker et al. 2009) and by the Gaussian09 (Frisch et al. 2009) program packages.

\section{Table 3}

Computed (B3LYP/6-31++G(d,p)) thermochemical data of the conformers of $(S, R)-\mathbf{1},(S, S)-\mathbf{2}, \quad(S, R, S, S)$ 3and ( $S, S, S, R)-\mathbf{4}$

\begin{tabular}{|l|l|l|l|}
\hline Conformer & $\Delta G \circ 0 \mathrm{~K}^{\text {a }}$ & $\Delta G \circ T(\mathrm{ev})^{\mathbf{b}}$ & $p i / \Sigma p i^{\mathbf{c}}$ \\
\hline
\end{tabular}




\begin{tabular}{|c|c|c|c|}
\hline Conformer & $\Delta G \circ 0 \mathrm{~K}^{\mathrm{a}}$ & $\Delta G \circ T(\mathrm{ev})^{\mathbf{b}}$ & $p i / \Sigma p i^{\mathrm{c}}$ \\
\hline \multicolumn{4}{|l|}{$(S, R)-\mathbf{1}$} \\
\hline $\mathrm{Z}_{8}^{\mathrm{P}}$ & 0.00 & 0.00 & 0.60 \\
\hline $\mathrm{Z}_{6}{ }^{\mathrm{P}}$ & 0.45 & 1.18 & 0.40 \\
\hline \multicolumn{4}{|l|}{$(S, S)-\mathbf{2}$} \\
\hline $\mathrm{S}^{\mathrm{M}}$ & 3.26 & 3.35 & 0.25 \\
\hline $\mathrm{H}_{8}{ }^{\mathrm{P}}$ & 0.00 & 0.00 & 0.75 \\
\hline \multicolumn{4}{|l|}{$(S, R, S, S)-\mathbf{3}$} \\
\hline $\mathrm{Z}_{6}{ }^{\mathrm{P}} \mathrm{H}_{8}{ }^{\mathrm{P}}$ & 0.00 & 0.00 & 0.50 \\
\hline $\mathrm{Z}_{6}{ }^{\mathrm{P}} \mathrm{S}^{\mathrm{M}}$ & 3.18 & 1.27 & 0.36 \\
\hline $\mathrm{Z}_{8}{ }^{* \mathrm{P}} \mathrm{H}_{8}{ }^{\mathrm{P}}$ & 5.13 & 6.03 & 0.10 \\
\hline $\mathrm{Z}_{8}{ }^{* \mathrm{P}} \mathrm{S}^{\mathrm{M}}$ & 9.72 & 9.80 & 0.04 \\
\hline \multicolumn{4}{|l|}{$(S, S, S, R)-\mathbf{4}$} \\
\hline $\mathrm{H}_{8}{ }^{\mathrm{P}} \mathrm{Z}_{8}{ }^{\mathrm{P}}$ & 0.00 & 0.22 & 0.35 \\
\hline $\mathrm{S}^{\mathrm{M}} \mathrm{Z}_{6}{ }^{\mathrm{P}}$ & 2.75 & 0.00 & 0.37 \\
\hline $\mathrm{S}^{\mathrm{M}} \mathrm{Z}_{8}{ }^{\mathrm{P}}$ & 3.29 & 1.09 & 0.28 \\
\hline
\end{tabular}

${ }^{\mathrm{a}}$ Gibbs free $(\Delta G \circ 0 \mathrm{~K})$ energies at $0 \mathrm{~K}$ in kJ mol ${ }^{-1}$

${ }^{\mathrm{b}}$ Gibbs free $(\Delta G \circ T(\mathrm{ev}))$ energies at temperature of sample evaporation $(350,365,446$, and $443 \mathrm{~K}$, respectively) in $\mathrm{kJ} \mathrm{mol}^{-1}$

${ }^{\mathrm{c}}$ Boltzmann factors $(p i / \Sigma p i)$ at the temperature of sample evaporation

Table 4

Computed (SQM B3LYP/6-31++G(d,p)) fundamental frequencies $\left(v \sim\right.$ in $\mathrm{cm}^{-1}$ ), intensities (in $\mathrm{km} \mathrm{mol}^{-1}$ ) and experimental vibrational transitions $\left(\mathcal{V} \sim\right.$ in $\left.\mathrm{cm}^{-1}\right)$ of the $\mathrm{Z}_{6}{ }^{\mathrm{P}}$ and $\mathrm{Z}_{8}{ }^{\mathrm{P}}$ conformers of $(S, R)-\mathbf{1}$

\begin{tabular}{|c|c|c|c|c|c|}
\hline \multicolumn{3}{|l|}{$Z_{6}{ }^{P}$} & \multicolumn{3}{|l|}{$Z_{8}{ }^{P}$} \\
\hline \multicolumn{2}{|c|}{ Computed } & \multirow{2}{*}{$\begin{array}{l}\text { Ar matrix } \\
\mathcal{v} \sim, \text { Intensity }^{\mathrm{a}}\end{array}$} & \multicolumn{2}{|c|}{ Computed } & \multirow{2}{*}{$\begin{array}{l}\text { Ar matrix } \\
v \sim, \text { Intensity }^{\mathrm{a}}\end{array}$} \\
\hline$v \sim$ & $I$ & & $v \sim$ & $I$ & \\
\hline 21.6 & 3.9 & & 41.6 & 13.9 & \\
\hline 34.5 & 0.2 & & 56.6 & 1.5 & \\
\hline 53.1 & 5.2 & & 62.4 & 9.6 & \\
\hline
\end{tabular}




\begin{tabular}{|c|c|c|c|c|c|}
\hline \multicolumn{3}{|l|}{$Z_{6}{ }^{P}$} & \multicolumn{3}{|l|}{$Z_{8}^{P}$} \\
\hline \multicolumn{2}{|c|}{ Computed } & \multirow{2}{*}{$\begin{array}{l}\text { Ar matrix } \\
v \sim, \text { Intensity }^{\mathbf{a}}\end{array}$} & \multicolumn{2}{|c|}{ Computed } & \multirow{2}{*}{$\begin{array}{l}\text { Ar matrix } \\
v \sim, \text { Intensity }^{\mathbf{a}}\end{array}$} \\
\hline$v \sim$ & $I$ & & $v \sim$ & $I$ & \\
\hline 66.4 & 5.6 & & 72.3 & 2.7 & \\
\hline 87.7 & 11.6 & & 75.8 & 7.8 & \\
\hline 92.2 & 3.9 & & 87.9 & 4.8 & \\
\hline 139.9 & 0.6 & & 119.9 & 1.3 & \\
\hline 157.7 & 8.8 & & 170.1 & 7.4 & \\
\hline 214.3 & 0.3 & & 201.8 & 4.7 & \\
\hline 243.9 & 7.8 & & 226.0 & 0.7 & \\
\hline 284.7 & 6.1 & & 310.5 & 7.3 & \\
\hline 342.8 & 10.2 & & 327.5 & 10.8 & \\
\hline 362.4 & 15.5 & & 376.2 & 2.8 & \\
\hline 424.9 & 4.1 & & 413.8 & 73.7 & $420 \mathrm{br}, \mathrm{ur}$ \\
\hline 473.4 & 15.1 & $467 \mathrm{vw}$ & 420.1 & 16.7 & $420 \mathrm{br}, \mathrm{ur}$ \\
\hline 509.0 & 48.8 & $500 \mathrm{w}, \mathrm{ur}$ & 505.6 & 4.9 & $500 \mathrm{w}$, ur \\
\hline 561.5 & 69.6 & $581 \mathrm{w}$ & 549.6 & 91.7 & $558 \mathrm{w}$ \\
\hline 573.1 & 13.5 & & 578.8 & 13.8 & $589 \mathrm{vw}, \mathrm{sh}$ \\
\hline 653.7 & 20.6 & $656 \mathrm{w}$ & 627.4 & 0.8 & $626 \mathrm{vw}$ \\
\hline 662.8 & 20.6 & $675 \mathrm{w}$ & 649.7 & 19.8 & $644 \mathrm{vw}$ \\
\hline 732.0 & 4.5 & $715 \mathrm{vw}$ & 690.8 & 2.5 & $691 \mathrm{vw}$ \\
\hline 758.1 & 2.5 & 732 vw & 762.6 & 2.1 & $745 \mathrm{vW}$ \\
\hline 777.6 & 4.9 & $780 \mathrm{vw}$ & 776.9 & 3.3 & $771 \mathrm{vw}$ \\
\hline 846.3 & 2.4 & $851 \mathrm{vw}$ & 846.0 & 4.4 & $851 \mathrm{vw}$ \\
\hline 882.3 & 1.3 & & 898.0 & 1.4 & \\
\hline 910.4 & 1.2 & & 917.0 & 1.4 & \\
\hline 926.9 & 1.9 & & 923.0 & 0.9 & \\
\hline
\end{tabular}




\begin{tabular}{|c|c|c|c|c|c|}
\hline \multicolumn{3}{|l|}{$Z_{6}{ }^{P}$} & \multicolumn{3}{|l|}{$Z_{8}^{P}$} \\
\hline \multicolumn{2}{|l|}{ Computed } & \multirow{2}{*}{$\begin{array}{l}\text { Ar matrix } \\
v \sim, \text { Intensity }^{\mathbf{a}}\end{array}$} & \multicolumn{2}{|c|}{ Computed } & \multirow{2}{*}{$\begin{array}{l}\text { Ar matrix } \\
v \sim, \text { Intensity }^{\mathbf{a}}\end{array}$} \\
\hline$v \sim$ & $I$ & & $v \sim$ & $I$ & \\
\hline 946.1 & 3.6 & $937 \mathrm{vw}$ & 954.7 & 3.9 & $960 \mathrm{vw}$ \\
\hline 966.3 & 3.0 & $964 \mathrm{vw}$ & 974.2 & 2.4 & 985 br, vw \\
\hline 992.0 & 6.3 & 998 sh, vw & 994.4 & 7.0 & $1,000 \mathrm{vw}$ \\
\hline $1,035.3$ & 3.9 & $1,025 \mathrm{vw}$ & $1,037.2$ & 7.1 & $1,037 \mathrm{w}$ \\
\hline $1,050.6$ & 14.7 & $1,058 \mathrm{vw}$ & $1,061.9$ & 10.6 & $1,073 \mathrm{w}$ \\
\hline $1,071.7$ & 1.4 & & $1,068.4$ & 1.0 & \\
\hline $1,083.9$ & 4.1 & $1,092 \mathrm{vw}$ & $1,094.1$ & 1.7 & $1,099 \mathrm{vw}$ \\
\hline $1,128.2$ & 2.4 & $1,120 \mathrm{vw}$ & $1,124.8$ & 9.4 & $1,130 \mathrm{vw}, \mathrm{ur}$ \\
\hline $1,141.7$ & 24.3 & $1,143 \mathrm{vw}$ & $1,126.1$ & 14.8 & $1,130 \mathrm{vw}, \mathrm{ur}$ \\
\hline $1,152.9$ & 38.0 & $1,151 \mathrm{vw}$ & $1,166.1$ & 0.7 & $1,165 \mathrm{vw}$ \\
\hline $1,182.5$ & 34.3 & $1,180 \mathrm{vw}$ & $1,194.7$ & 1.0 & $1,186 \mathrm{vw}$ \\
\hline $1,203.0$ & 105.6 & $1,208 \mathrm{~m}, \mathrm{br}$ & $1,217.9$ & 46.5 & $1,217 \mathrm{w}$ \\
\hline $1,212.9$ & 8.5 & $1,214 \mathrm{sh}, \mathrm{w}$ & $1,226.3$ & 28.1 & $1,221 \mathrm{sh}$ \\
\hline $1,237.5$ & 39.8 & $1,232 \mathrm{~m}$ & $1,235.0$ & 30.8 & $1,238 \mathrm{w}$ \\
\hline $1,243.1$ & 3.0 & & $1,247.3$ & 1.0 & \\
\hline $1,251.8$ & 19.7 & $1,247 \mathrm{w}$ & $1,261.6$ & 76.2 & $1,262 \mathrm{~m}, 1,258 \mathrm{~m}, \mathrm{sh}$ \\
\hline $1,266.6$ & 65.4 & $1,274 \mathrm{sh}, \mathrm{m}$ & $1,270.3$ & 1.3 & \\
\hline $1,341.4$ & 35.3 & $1,333 \mathrm{w}$ & $1,338.2$ & 16.3 & $1,338 \mathrm{w}, \mathrm{sh}$ \\
\hline $1,360.9$ & 13.4 & $1,366 \mathrm{~m}, \mathrm{ur}$ & $1,368.5$ & 35.2 & $1,366 \mathrm{~m}, \mathrm{ur}$ \\
\hline $1,368.5$ & 58.2 & $1,369 \mathrm{~m}$ & $1,376.7$ & 2.4 & $1,374 \mathrm{vw}, \mathrm{sh}$ \\
\hline $1,409.9$ & 22.6 & $1,410 \mathrm{w}$ & $1,416.9$ & 9.3 & $1,418 \mathrm{w}$ \\
\hline $1,439.3$ & 7.7 & $1,443 \mathrm{sh}, \mathrm{w}$ & $1,436.8$ & 9.2 & $1,432 \mathrm{w}$ \\
\hline $1,447.8$ & 5.2 & $1,448 \mathrm{w}, \mathrm{br}, \mathrm{ur}$ & $1,441.8$ & 2.4 & $1,436 \mathrm{vw}$ \\
\hline $1,451.2$ & 19.8 & $1,448 \mathrm{w}, \mathrm{br}, \mathrm{ur}$ & $1,447.7$ & 25.6 & $1,448 \mathrm{w}, \mathrm{br}, \mathrm{ur}$ \\
\hline
\end{tabular}




\begin{tabular}{|c|c|c|c|c|c|}
\hline \multicolumn{3}{|l|}{$\mathrm{Z}_{6}{ }^{\mathrm{P}}$} & \multicolumn{3}{|l|}{$Z_{8}^{P}$} \\
\hline \multicolumn{2}{|l|}{ Computed } & \multirow{2}{*}{$\begin{array}{l}\text { Ar matrix } \\
v \sim, \text { Intensity }^{\mathrm{a}}\end{array}$} & \multicolumn{2}{|c|}{ Computed } & \multirow{2}{*}{$\begin{array}{l}\text { Ar matrix } \\
v \sim, \text { Intensity }^{\mathrm{a}}\end{array}$} \\
\hline$v \sim$ & $I$ & & $v \sim$ & $I$ & \\
\hline $1,458.6$ & 66.4 & $1,448 \mathrm{w}, \mathrm{br}, \mathrm{ur}$ & $1,451.0$ & 22.9 & $1,448 \mathrm{w}, \mathrm{br}, \mathrm{ur}$ \\
\hline $1,465.8$ & 8.5 & $1,472 \mathrm{w}$, ur & $1,464.4$ & 9.9 & $1,464 \mathrm{vw}$ \\
\hline $1,467.0$ & 7.9 & $1,472 \mathrm{w}, \mathrm{ur}$ & $1,473.4$ & 4.0 & $1,476 \mathrm{vw}$ \\
\hline $1,508.5$ & 428.1 & $1,505 \mathrm{sh}$ & $1,498.9$ & 225.8 & $1,499 \mathrm{~s}$ \\
\hline $1,534.5$ & 172.2 & $1,521 \mathrm{sh}$ & $1,538.6$ & 223.3 & $1,532 \mathrm{~s}$ \\
\hline $1,667.3$ & 185.7 & $1,682 \mathrm{vs}, \mathrm{ur}$ & $1,667.3$ & 116.0 & $1,682 \mathrm{vs}, \mathrm{ur}$ \\
\hline $1,685.6$ & 322.4 & 1,697 vs, ur & $1,683.4$ & 338.3 & 1,697 vs, ur \\
\hline $2,914.4$ & 65.7 & $2,911 \mathrm{w}$ & $2,903.2$ & 52.9 & $2,911 \mathrm{w}$ \\
\hline $2,927.4$ & 9.7 & & $2,928.8$ & 7.5 & \\
\hline $2,934.9$ & 27.8 & $2,936 \mathrm{sh}, \mathrm{w}, \mathrm{ur}$ & $2,932.7$ & 33.5 & $2,936 \mathrm{sh}, \mathrm{w}, \mathrm{ur}$ \\
\hline $2,944.4$ & 42.7 & $2,936 \mathrm{sh}, \mathrm{w}, \mathrm{ur}$ & $2,950.0$ & 10.3 & $2,936 \mathrm{sh}, \mathrm{w}, \mathrm{ur}$ \\
\hline $2,949.8$ & 35.7 & $2,951 \mathrm{w}$ & $2,952.3$ & 20.7 & $2,951 \mathrm{w}$ \\
\hline $2,968.8$ & 25.3 & $2,969 \mathrm{w}$ & $2,967.0$ & 21.4 & $2,961 \mathrm{w}$ \\
\hline $2,989.6$ & 3.6 & & $2,979.2$ & 27.7 & $2,985 \mathrm{w}$ \\
\hline $2,996.8$ & 13.4 & $3,004 \mathrm{w}$ & $2,987.5$ & 40.7 & $2,985 \mathrm{w}$ \\
\hline $3,001.3$ & 7.6 & & $3,000.6$ & 8.4 & \\
\hline $3,005.5$ & 12.6 & $3,014 \mathrm{sh}, \mathrm{vw}$ & $3,009.3$ & 10.5 & $3,014 \mathrm{sh}, \mathrm{vw}$ \\
\hline $3,010.4$ & 29.9 & $3,014 \mathrm{sh}, \mathrm{vw}$ & $3,019.7$ & 5.8 & \\
\hline $3,032.9$ & 0.7 & & $3,020.0$ & 14.0 & \\
\hline $3,432.0$ & 69.3 & 3,465 m-w & $3,414.5$ & 65.0 & $\begin{array}{l}3,429 \mathrm{~m}, 3,422 \mathrm{~m}, 3412 \\
\mathrm{sh}\end{array}$ \\
\hline $3,470.9$ & 28.9 & $\begin{array}{l}3,487 \text { w, } 3482 \\
\text { w }\end{array}$ & $3,462.5$ & 28.0 & $3,494 \mathrm{w}$ \\
\hline
\end{tabular}

The assignments of the very weak and the unresolved lines, as well as that of the bands in the $\mathrm{C}-\mathrm{H}$ and the amide A ( $\mathrm{N}-\mathrm{H}$ stretching) are tentative

${ }^{a} v w$ very weak, $w$ weak, $m$ medium, $s$ strong, $v s$ very strong, $s h$ shoulder, $b r$ broad, $u r$ unresolved bands. In case of site splitting more than one numbers are given 
Table 5

Computed (SQM B3LYP/6-31++G(d,p)) fundamental frequencies $\left(\mathcal{V} \sim\right.$ in $\left.\mathrm{cm}^{-1}\right)$, intensities (in $\left.\mathrm{km} \mathrm{mol}^{-1}\right)$ and experimental vibrational transitions $\left(\mathcal{V} \sim\right.$ in $\left.\mathrm{cm}^{-1}\right)$ of the $\mathrm{H}_{8}{ }^{\mathrm{P}}$ and $\mathrm{S}^{\mathrm{M}}$ conformers of $(S, S)-2$

\begin{tabular}{|c|c|c|c|c|c|}
\hline \multicolumn{3}{|l|}{$\mathrm{H}_{8}^{\mathrm{P}}$} & \multicolumn{3}{|l|}{$\mathbf{S}^{\mathbf{M}}$} \\
\hline \multicolumn{2}{|c|}{ Computed } & \multirow{2}{*}{$\begin{array}{l}\text { Ar matrix } \\
v \sim, \text { Intensity }^{\mathrm{a}}\end{array}$} & \multicolumn{2}{|c|}{ Computed } & \multirow{2}{*}{$\begin{array}{l}\text { Ar matrix } \\
v \sim, \text { Intensity }^{\mathrm{a}}\end{array}$} \\
\hline$v \sim$ & $I$ & & $v \sim$ & $I$ & \\
\hline 44.4 & 0.7 & & 25.0 & 6.8 & \\
\hline 54.0 & 5.2 & & 28.8 & 0.9 & \\
\hline 67.9 & 1.6 & & 48.7 & 2.1 & \\
\hline 81.7 & 4.2 & & 64.0 & 9.7 & \\
\hline 99.2 & 2.5 & & 74.2 & 9.1 & \\
\hline 118.0 & 9.7 & & 113.2 & 1.6 & \\
\hline 136.8 & 4.7 & & 134.0 & 1.2 & \\
\hline 160.1 & 1.2 & & 161.9 & 8.1 & \\
\hline 196.5 & 6.6 & & 198.6 & 4.1 & \\
\hline 273.4 & 10.3 & & 235.6 & 6.3 & \\
\hline 282.0 & 8.9 & & 300.9 & 9.0 & \\
\hline 323.5 & 3.6 & & 339.5 & 14.5 & \\
\hline 349.8 & 8.8 & & 353.1 & 9.2 & \\
\hline 418.8 & 18.3 & $426 \mathrm{w}$ & 435.0 & 37.8 & $426 \mathrm{w}, \mathrm{sh}^{\mathrm{b}}$ \\
\hline 443.2 & 50.2 & $448 \mathrm{~m}$ & 450.5 & 37.9 & $459 \mathrm{w}, \mathrm{sh}$ \\
\hline 493.0 & 18.8 & $494 \mathrm{~m}$ & 469.3 & 18.6 & $480 w^{b}$ \\
\hline 547.4 & 3.2 & $549 w$ & 496.5 & 52.8 & $503 \mathrm{w}, \mathrm{sh}^{\mathrm{b}}$ \\
\hline 599.9 & 6.5 & $601 \mathrm{w}, 606 \mathrm{w}$ & 560.9 & 7.7 & $572 \mathrm{w}$ \\
\hline 630.4 & 8.6 & $628 \mathrm{w}$ & 629.2 & 0.2 & $705 \mathrm{vw}, \mathrm{sh}$ \\
\hline 679.0 & 20.3 & $673 w$ & 695.5 & 1.9 & \\
\hline 710.6 & 26.4 & $698 \mathrm{w}$ & 715.5 & 1.0 & \\
\hline 765.5 & 2.1 & $767 \mathrm{w}$ & 723.8 & 2.0 & $741 \mathrm{vw}, 743 \mathrm{w}$ \\
\hline
\end{tabular}




\begin{tabular}{|c|c|c|c|c|c|}
\hline \multicolumn{3}{|l|}{$\mathrm{H}_{8}^{\mathrm{P}}$} & \multicolumn{3}{|l|}{$\mathbf{S}^{\mathbf{M}}$} \\
\hline \multicolumn{2}{|l|}{ Computed } & \multirow{2}{*}{$\begin{array}{l}\text { Ar matrix } \\
v \sim, \text { Intensity }^{\mathbf{a}}\end{array}$} & \multicolumn{2}{|c|}{ Computed } & \multirow{2}{*}{$\begin{array}{l}\text { Ar matrix } \\
v \sim, \text { Intensity }^{\mathrm{a}}\end{array}$} \\
\hline$v \sim$ & $I$ & & $v \sim$ & $I$ & \\
\hline 809.6 & 0.3 & $808 \mathrm{w}, \mathrm{sh}$ & 810.8 & 0.7 & \\
\hline 820.8 & 2.6 & $824 \mathrm{w}$ & 828.5 & 0.3 & \\
\hline 909.7 & 1.9 & $899 \mathrm{vw}$ & 883.5 & 7.5 & $880 \mathrm{vw}$ \\
\hline 919.0 & 1.0 & $912 \mathrm{vw}, \mathrm{sh}$ & 906.0 & 1.0 & \\
\hline 939.2 & 3.9 & $932 \mathrm{w}$ & 926.8 & 5.1 & 919 vw \\
\hline 953.2 & 2.7 & $949 \mathrm{vw}$ & 953.9 & 2.1 & \\
\hline 991.6 & 6.5 & 998 w & 977.1 & 4.4 & 972 w, ur \\
\hline $1,001.5$ & 0.9 & $1,009 \mathrm{w}$ & 986.6 & 10.5 & 972 w, ur \\
\hline $1,038.1$ & 6.3 & $1,037 \mathrm{w}$ & $1,035.3$ & 5.5 & \\
\hline $1,058.9$ & 1.5 & $1,066 \mathrm{w}$ & $1,045.5$ & 6.1 & \\
\hline $1,087.9$ & 0.7 & $1,077 \mathrm{vw}$ & $1,078.0$ & 7.1 & \\
\hline $1,100.3$ & 5.1 & $1,104 \mathrm{vw}$ & $1,106.6$ & 5.5 & \\
\hline $1,124.1$ & 12.5 & $1,113 \mathrm{w}$ & $1,119.8$ & 8.0 & $1,116 \mathrm{w}$ \\
\hline $1,131.6$ & 0.4 & $1,136 \mathrm{w}$ & $1,128.4$ & 0.6 & \\
\hline $1,170.5$ & 1.1 & $1,165 \mathrm{w}$ & $1,150.5$ & 32.9 & $1,157 \mathrm{w}$ \\
\hline $1,196.0$ & 1.9 & $1,203 \mathrm{w}$ & 1,193.6 & 56.9 & $\begin{array}{l}1,184 \mathrm{w}, 1,186 \\
\mathrm{~W}\end{array}$ \\
\hline $1,208.7$ & 0.2 & & $1,198.7$ & 32.2 & $1,208 \mathrm{w}$ \\
\hline $1,231.8$ & 4.7 & $1,232 \mathrm{vw}$ & $1,226.9$ & 20.8 & $1,226 \mathrm{vw}$ \\
\hline $1,240.3$ & 5.4 & $1,240 \mathrm{w}$, ur & $1,229.7$ & 12.5 & \\
\hline $1,243.6$ & 15.3 & $1,240 \mathrm{w}, \mathrm{ur}$ & $1,249.4$ & 21.7 & \\
\hline $1,266.6$ & 65.3 & $1,264 \mathrm{~m}$ & $1,256.0$ & 27.9 & $1,251 \mathrm{w}, \mathrm{ur}$ \\
\hline $1,286.7$ & 78.2 & $1,281 \mathrm{~m}, 1291 \mathrm{w}, \mathrm{sh}$ & $1,257.3$ & 121.9 & $1,251 \mathrm{w}$, ur \\
\hline $1,316.2$ & 12.9 & $1,325 \mathrm{w}$ & $1,353.1$ & 17.5 & \\
\hline
\end{tabular}




\begin{tabular}{|c|c|c|c|c|c|}
\hline \multicolumn{3}{|l|}{$\mathbf{H}_{8}{ }^{\mathrm{P}}$} & \multicolumn{3}{|l|}{$\mathbf{S}^{\mathbf{M}}$} \\
\hline \multicolumn{2}{|l|}{ Computed } & \multirow{2}{*}{$\begin{array}{l}\text { Ar matrix } \\
v \sim, \text { Intensity }^{\mathbf{a}}\end{array}$} & \multicolumn{2}{|c|}{ Computed } & \multirow{2}{*}{$\begin{array}{l}\text { Ar matrix } \\
v \sim, \text { Intensity }^{\mathrm{a}}\end{array}$} \\
\hline$v \sim$ & $I$ & & $v \sim$ & $I$ & \\
\hline $1,363.4$ & 8.0 & $1,363 \mathrm{w}$ & $1,368.0$ & 32.7 & \\
\hline $1,374.3$ & 21.5 & $1,374 \mathrm{~m}$ & $1,401.1$ & 61.1 & $1,408 \mathrm{vw}$ \\
\hline $1,423.3$ & 6.3 & $1,414 \mathrm{w}$ & $1,409.8$ & 34.1 & \\
\hline $1,437.1$ & 8.3 & $1,430 \mathrm{w}$ & $1,437.8$ & 7.3 & \\
\hline $1,445.6$ & 7.7 & $1,445 \mathrm{~m}, \mathrm{ur}$ & $1,450.9$ & 8.5 & \\
\hline $1,451.3$ & 32.8 & $1,445 \mathrm{~m}, \mathrm{ur}$ & $1,451.9$ & 13.2 & \\
\hline $1,455.0$ & 0.3 & & $1,458.6$ & 57.9 & $1,463 \mathrm{w}$ \\
\hline $1,474.5$ & 1.3 & $1,473 \mathrm{w}, \mathrm{ur}$ & $1,466.7$ & 7.0 & \\
\hline $1,475.4$ & 2.2 & $1,473 \mathrm{w}, \mathrm{ur}$ & $1,473.4$ & 26.7 & \\
\hline $1,505.7$ & 235.9 & $1,505 \mathrm{~s}, \mathrm{br}$ & $1,514.4$ & 168.1 & $(1,505 \mathrm{~s}, \mathrm{br}, \mathrm{ur})$ \\
\hline $1,569.4$ & 203.2 & $1,568 \mathrm{~s}, \mathrm{br}$ & $1,530.3$ & 204.0 & $1,519 \mathrm{~m}, \mathrm{br}$ \\
\hline $1,662.7$ & 327.7 & $1,678 \mathrm{vs}$ & $1,682.3$ & 220.7 & (1,687 vs, ur) \\
\hline $1,673.9$ & 296.9 & $1,687 \mathrm{vs}$ & $1,685.3$ & 221.0 & (1,687 vs, ur) \\
\hline $2,916.5$ & 69.3 & $2,912 \mathrm{w}, \mathrm{ur}$ & $2,910.4$ & 72.3 & \\
\hline $2,917.8$ & 21.9 & $2,912 \mathrm{w}, \mathrm{ur}$ & $2,927.3$ & 10.6 & \\
\hline $2,926.6$ & 7.6 & & $2,945.5$ & 38.1 & \\
\hline $2,929.9$ & 9.1 & & $2,951.1$ & 44.3 & \\
\hline $2,959.1$ & 9.0 & & $2,962.9$ & 29.3 & \\
\hline $2,960.9$ & 15.8 & $2,954 \mathrm{w}$ & $2,971.9$ & 1.5 & \\
\hline $2,971.3$ & 24.2 & $2,970 \mathrm{w}$ & $2,984.3$ & 4.5 & \\
\hline $2,983.5$ & 37.3 & $2,993 \mathrm{w}$ & $3,002.2$ & 7.5 & \\
\hline $3,004.9$ & 6.8 & & $3,002.4$ & 15.2 & \\
\hline $3,007.5$ & 12.0 & $3,007 \mathrm{w}, \mathrm{br}, \mathrm{ur}$ & $3,004.2$ & 7.7 & \\
\hline $3,013.9$ & 17.1 & $3,007 \mathrm{w}, \mathrm{br}, \mathrm{ur}$ & $3,020.2$ & 21.5 & \\
\hline
\end{tabular}




\begin{tabular}{|c|c|c|c|c|c|}
\hline \multicolumn{3}{|l|}{$\mathrm{H}_{8}{ }^{\mathrm{P}}$} & \multicolumn{3}{|l|}{$\mathbf{S}^{\mathbf{M}}$} \\
\hline \multicolumn{2}{|l|}{ Computed } & \multirow{2}{*}{$\begin{array}{l}\text { Ar matrix } \\
v \sim, \text { Intensity }^{\mathbf{a}}\end{array}$} & \multicolumn{2}{|c|}{ Computed } & \multirow{2}{*}{$\begin{array}{l}\text { Ar matrix } \\
v \sim, \text { Intensity }^{\mathrm{a}}\end{array}$} \\
\hline$v \sim$ & $I$ & & $v \sim$ & $I$ & \\
\hline $3,014.9$ & 22.5 & $3,007 \mathrm{w}, \mathrm{br}, \mathrm{ur}$ & $3,029.9$ & 0.9 & \\
\hline $3,299.4$ & 430.0 & $3,308 \mathrm{~s}, 3,299 \mathrm{~m}, \mathrm{sh}$ & $3,467.7$ & 24.0 & $3,514 \mathrm{w}, \mathrm{br}$, ur \\
\hline $3,458.9$ & 24.2 & $\begin{array}{l}3,463 \mathrm{~m}, 3,469 \mathrm{w}, 3483 \\
\mathrm{w}\end{array}$ & 3469.8 & 24.4 & $3,514 \mathrm{w}, \mathrm{br}$, ur \\
\hline
\end{tabular}

The assignments of the very weak and the unresolved lines, as well as that of the bands in the $\mathrm{C}-\mathrm{H}$ and the amide A $(\mathrm{N}-\mathrm{H}$ stretching) regions are tentative. In the case of conformer E only the bands well resolved from the bands of conformer $\mathrm{H}_{8}{ }^{\mathrm{P}}$ are listed

${ }^{a} v w$ very weak, $w$ weak, $m$ medium, $s$ strong, $v s$ very strong, $s h$ shoulder, $b r$ broad, $u r$ unresolved bands. In case of site splitting more than one numbers are given

${ }^{\mathrm{b}}$ Uncertain assignment

Table 6

Computed (SQM B3LYP/6-31++G(d,p)) amide I and amide A frequencies $\left(v \sim\right.$ in $\mathrm{cm}^{-1}$ ), intensities (in $\left.\mathrm{km} \mathrm{mol}^{-1}\right)$ and experimental vibrational transitions $\left(\mathcal{V} \sim\right.$ in $\left.\mathrm{cm}^{-1}\right)$ of the four low-energy conformers of $(S, R, S, S)$ 3

\begin{tabular}{|c|c|c|c|c|c|c|c|c|c|c|c|}
\hline \multicolumn{3}{|c|}{$\mathrm{Z}_{6}{ }^{\mathrm{P}} \mathrm{H}_{8}{ }^{\mathrm{P}}$} & \multicolumn{3}{|c|}{$\mathrm{Z}_{8}{ }^{* \mathrm{P}} \mathrm{H}_{8}{ }^{\mathrm{P}}$} & \multicolumn{3}{|c|}{$\mathrm{Z}_{6}{ }^{\mathrm{P}} \mathrm{S}^{\mathrm{M}}$} & \multicolumn{3}{|c|}{$\mathrm{Z}_{8}{ }^{* \mathrm{P}} \mathrm{S}^{\mathrm{M}}$} \\
\hline \multicolumn{2}{|c|}{ Computed } & \multirow{2}{*}{$\begin{array}{l}\begin{array}{l}\text { Ar } \\
\text { matrix }\end{array} \\
\qquad \sim, \\
\begin{array}{l}\text { Int } \\
\text { ensi } \\
\text { ty }\end{array}\end{array}$} & \multicolumn{2}{|c|}{ Computed } & \multirow{2}{*}{$\begin{array}{l}\begin{array}{l}\text { Ar } \\
\text { matrix }\end{array} \\
\qquad \begin{array}{l}v \sim, \\
\text { Int } \\
\text { ensi } \\
\text { ty }\end{array}\end{array}$} & \multicolumn{2}{|c|}{ Computed } & \multirow{2}{*}{$\begin{array}{l}\text { Ar } \\
\text { mat } \\
\text { rix }\end{array}$} & \multicolumn{2}{|c|}{ Computed } & \multirow{2}{*}{$\begin{array}{l}\text { Ar } \\
\text { mat } \\
\text { rix }\end{array}$} \\
\hline $\mathcal{~ v ~}$ & $I$ & & $\mathcal{~ \nu ~}$ & $I$ & & $v^{\sim}$ & $I$ & & $v \sim$ & $I$ & \\
\hline $\begin{array}{l}1, \\
63 \\
8 . \\
3\end{array}$ & $\begin{array}{l}2 \\
0 \\
3 . \\
5\end{array}$ & $\begin{array}{l}1,6 \\
37 \\
\mathrm{~m}- \\
\mathrm{s}, \\
\text { ur }\end{array}$ & $\begin{array}{l}1, \\
63 \\
7 . \\
7\end{array}$ & $\begin{array}{l}3 \\
5 \\
4 . \\
0\end{array}$ & $\begin{array}{l}1,6 \\
37 \\
\text { m- } \\
\text { s, } \\
\text { ur }\end{array}$ & $\begin{array}{l}1, \\
65 \\
8 . \\
0\end{array}$ & $\begin{array}{l}1 \\
2 \\
5 . \\
3\end{array}$ & $\begin{array}{l}1,6 \\
63 \\
s, \\
\text { ur }\end{array}$ & $\begin{array}{l}1, \\
65 \\
7 . \\
8\end{array}$ & $\begin{array}{l}2 \\
2 \\
6 . \\
5\end{array}$ & $\begin{array}{l}1,6 \\
63 \\
\mathrm{~s}, \\
\text { ur }\end{array}$ \\
\hline $\begin{array}{l}1, \\
67 \\
2 . \\
8\end{array}$ & $\begin{array}{l}3 \\
3 \\
6 . \\
6\end{array}$ & $\begin{array}{l}1,6 \\
85 \\
\text { vs, } \\
\text { ur }\end{array}$ & $\begin{array}{l}1, \\
66 \\
6 . \\
8\end{array}$ & $\begin{array}{l}3 \\
1 \\
5\end{array}$ & $\begin{array}{l}1,6 \\
78 \\
\text { s, } \\
\text { sh }\end{array}$ & $\begin{array}{l}1, \\
68 \\
2 . \\
5\end{array}$ & $\begin{array}{l}2 \\
3 \\
6 . \\
2\end{array}$ & $\begin{array}{l}1,6 \\
97 \\
\text { m, } \\
\text { sh, } \\
\text { ur }\end{array}$ & $\begin{array}{l}1, \\
67 \\
5 . \\
2\end{array}$ & $\begin{array}{l}2 \\
4 \\
9 . \\
0\end{array}$ & $\begin{array}{l}1,6 \\
85 \\
\text { vs, } \\
\text { ur }\end{array}$ \\
\hline $\begin{array}{l}1, \\
68\end{array}$ & $\begin{array}{l}3 \\
0\end{array}$ & $\begin{array}{l}1,6 \\
97\end{array}$ & $\begin{array}{l}1, \\
67\end{array}$ & 4 & $\begin{array}{l}1,6 \\
85\end{array}$ & $\begin{array}{l}1, \\
68\end{array}$ & $\begin{array}{l}3 \\
1\end{array}$ & $\begin{array}{l}1,6 \\
97\end{array}$ & $\begin{array}{l}1, \\
68\end{array}$ & $\begin{array}{l}2 \\
2\end{array}$ & $\begin{array}{l}1,6 \\
97\end{array}$ \\
\hline
\end{tabular}




\begin{tabular}{|c|c|c|c|c|c|c|c|c|c|c|c|}
\hline \multicolumn{3}{|c|}{$\mathrm{Z}_{6}{ }^{\mathrm{P}} \mathrm{H}_{8}{ }^{\mathrm{P}}$} & \multicolumn{3}{|c|}{$\mathrm{Z}_{8}{ }^{* \mathrm{P}} \mathbf{H}_{8}{ }^{\mathrm{P}}$} & \multicolumn{3}{|c|}{$Z_{6}{ }^{P} S^{M}$} & \multicolumn{3}{|c|}{$\mathrm{Z}_{\mathbf{8}}{ }^{* \mathbf{P}} \mathbf{S}^{\mathbf{M}}$} \\
\hline \multicolumn{2}{|c|}{ Computed } & \multirow{2}{*}{$\begin{array}{l}\begin{array}{l}\text { Ar } \\
\text { matrix }\end{array} \\
\qquad \sim, \\
\begin{array}{l}\text { Int } \\
\text { ensi } \\
\text { ty }\end{array}\end{array}$} & \multicolumn{2}{|c|}{ Computed } & \multirow{2}{*}{$\begin{array}{l}\begin{array}{l}\text { Ar } \\
\text { matrix }\end{array} \\
\qquad \sim, \\
\begin{array}{l}\text { Int } \\
\text { ensi } \\
\text { ty }\end{array}\end{array}$} & \multicolumn{2}{|c|}{ Computed } & \multirow{2}{*}{ 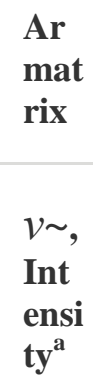 } & \multicolumn{2}{|c|}{ Computed } & \multirow{2}{*}{$\begin{array}{l}\text { Ar } \\
\text { mat } \\
\text { rix }\end{array}$} \\
\hline$v \sim$ & $I$ & & $v \sim$ & $I$ & & $v \sim$ & $I$ & & $v \sim$ & $I$ & \\
\hline $\begin{array}{l}9 . \\
7\end{array}$ & $\begin{array}{l}6 . \\
6\end{array}$ & $\begin{array}{l}\mathrm{m}, \\
\mathrm{sh}, \\
\text { ur }\end{array}$ & $\begin{array}{l}1 . \\
3\end{array}$ & $\begin{array}{l}5 . \\
4\end{array}$ & $\begin{array}{l}\text { vs, } \\
\text { ur }\end{array}$ & $\begin{array}{l}6 . \\
2\end{array}$ & $\begin{array}{l}9 . \\
4\end{array}$ & $\begin{array}{l}\mathrm{m}, \\
\mathrm{sh}, \\
\mathrm{ur}\end{array}$ & $\begin{array}{l}3 . \\
6\end{array}$ & $\begin{array}{l}1 . \\
9\end{array}$ & $\begin{array}{l}\mathrm{m}, \\
\mathrm{sh}, \\
\text { ur }\end{array}$ \\
\hline $\begin{array}{l}3, \\
31 \\
2 . \\
5\end{array}$ & $\begin{array}{l}4 \\
5 \\
7 . \\
3\end{array}$ & $\begin{array}{l}3,3 \\
03 \\
\mathrm{~m}, \\
\text { ur }\end{array}$ & $\begin{array}{l}3 \\
27 \\
2 . \\
4\end{array}$ & $\begin{array}{l}5 \\
2 \\
4 . \\
2\end{array}$ & $\begin{array}{l}3,3 \\
03 \\
\mathrm{~m}, \\
\text { ur }\end{array}$ & $\begin{array}{l}3, \\
43 \\
3 . \\
6\end{array}$ & $\begin{array}{l}8 \\
4 . \\
5\end{array}$ & $\begin{array}{l}3,4 \\
68 \\
\text { w, } \\
\text { ur }\end{array}$ & $\begin{array}{l}3, \\
30 \\
3 . \\
8\end{array}$ & $\begin{array}{l}3 \\
7 \\
2 . \\
7\end{array}$ & $\begin{array}{l}3,3 \\
03 \\
\text { m, } \\
\text { ur }\end{array}$ \\
\hline $\begin{array}{l}3, \\
44 \\
2 . \\
3\end{array}$ & $\begin{array}{l}5 \\
4 . \\
0\end{array}$ & $\begin{array}{l}3,4 \\
68 \\
\mathrm{w}, \\
\text { ur }\end{array}$ & $\begin{array}{l}3, \\
28 \\
3 . \\
7\end{array}$ & $\begin{array}{l}3 \\
0 \\
5 . \\
6\end{array}$ & $\begin{array}{l}3,3 \\
03 \\
\mathrm{~m}, \\
\text { ur }\end{array}$ & $\begin{array}{l}3, \\
46 \\
2 . \\
8\end{array}$ & $\begin{array}{l}2 \\
9 . \\
8\end{array}$ & $\begin{array}{l}3,5 \\
15 \\
\text { w, } \\
\text { ur }\end{array}$ & $\begin{array}{l}3, \\
46 \\
1 . \\
1\end{array}$ & $\begin{array}{l}2 \\
5 . \\
2\end{array}$ & $\begin{array}{l}3,5 \\
15 \\
\text { w, } \\
\text { ur }\end{array}$ \\
\hline $\begin{array}{l}3, \\
45 \\
3 . \\
7\end{array}$ & $\begin{array}{l}2 \\
9 . \\
5\end{array}$ & $\begin{array}{l}3,4 \\
68 \\
\text { w, } \\
\text { ur }\end{array}$ & $\begin{array}{l}3, \\
45 \\
9 . \\
6\end{array}$ & $\begin{array}{l}2 \\
6 \\
6\end{array}$ & $\begin{array}{l}3,5 \\
15 \\
\text { w, } \\
\text { ur }\end{array}$ & $\begin{array}{l}3, \\
46 \\
8 . \\
5\end{array}$ & $\begin{array}{l}2 \\
1 . \\
5\end{array}$ & $\begin{array}{l}3,5 \\
15 \\
\text { w, } \\
\text { ur }\end{array}$ & $\begin{array}{l}3, \\
47 \\
0 . \\
2\end{array}$ & $\begin{array}{l}2 \\
1 . \\
6\end{array}$ & $\begin{array}{l}3,5 \\
15 \\
\text { w, } \\
\text { ur }\end{array}$ \\
\hline
\end{tabular}

${ }^{\mathrm{a}} w$ weak, $m$ medium, $s$ strong, $v s$ very strong, $s h$ shoulder, $u r$ unresolved bands

Table 7

Computed (SQM B3LYP/6-31++G(d,p)) amide I and amide A frequencies $\left(\mathcal{~} \sim\right.$ in $\left.\mathrm{cm}^{-1}\right)$, intensities (in $\left.\mathrm{km} \mathrm{mol}^{-1}\right)$ and experimental vibrational transitions $\left(\mathcal{V} \sim\right.$ in $\left.\mathrm{cm}^{-1}\right)$ of the three low-energy conformers of $(S, S, S, R)$ 4

\begin{tabular}{|c|c|c|c|c|c|c|c|c|}
\hline \multicolumn{3}{|c|}{$\mathbf{H}_{8}{ }^{P} Z_{8}{ }^{P}$} & \multicolumn{3}{|l|}{$S^{M} Z_{8}{ }^{P}$} & \multicolumn{3}{|c|}{$S^{M} Z_{6}{ }^{P}$} \\
\hline \multicolumn{2}{|l|}{ Computed } & \multirow{2}{*}{$\begin{array}{c}\text { Ar matrix } \\
\\
v \sim, \\
\text { Intensi } \\
\text { ty }\end{array}$} & \multicolumn{2}{|c|}{ Computed } & \multirow{2}{*}{$\begin{array}{l}\begin{array}{l}\text { Ar } \\
\text { matrix }\end{array} \\
v \sim, \\
\text { Intensi } \\
\text { ty }^{\mathrm{a}}\end{array}$} & \multicolumn{2}{|c|}{ Computed } & \multirow{2}{*}{$\begin{array}{l}\begin{array}{l}\text { Ar } \\
\text { matrix }\end{array} \\
v \sim, \\
\begin{array}{l}\text { Intensi } \\
\text { ty }\end{array}\end{array}$} \\
\hline$v \sim$ & $I$ & & $v \sim$ & $I$ & & $v \sim$ & $I$ & \\
\hline $\begin{array}{l}1,641 \\
.4\end{array}$ & $\begin{array}{l}246 . \\
1\end{array}$ & $\begin{array}{l}1,656 \\
\mathrm{~s}\end{array}$ & $\begin{array}{l}1,653 \\
.8\end{array}$ & $\begin{array}{l}137 . \\
2\end{array}$ & $\begin{array}{l}1,672 \\
\mathrm{~m}\end{array}$ & $\begin{array}{l}1,668 \\
.9\end{array}$ & $\begin{array}{l}227 . \\
9\end{array}$ & $\begin{array}{l}1,683 \\
\text { vs, ur }\end{array}$ \\
\hline $\begin{array}{l}1,669 \\
.3\end{array}$ & $\begin{array}{l}264 . \\
5\end{array}$ & $\begin{array}{l}1,683 \\
\text { vs, ur }\end{array}$ & $\begin{array}{l}1,684 \\
.6\end{array}$ & $\begin{array}{l}188 . \\
4\end{array}$ & $\begin{array}{l}1,706 \\
\mathrm{~m}, \mathrm{sh}\end{array}$ & $\begin{array}{l}1,671 \\
.4\end{array}$ & $\begin{array}{l}175 . \\
1\end{array}$ & $\begin{array}{l}1,683 \\
\text { vs, ur }\end{array}$ \\
\hline
\end{tabular}




\begin{tabular}{|c|c|c|c|c|c|c|c|c|}
\hline \multicolumn{3}{|c|}{$\mathrm{H}_{8}{ }^{\mathrm{P}} \mathrm{Z}_{8}{ }^{\mathrm{P}}$} & \multicolumn{3}{|l|}{$S^{M} Z_{8}{ }^{P}$} & \multicolumn{3}{|c|}{$S^{M^{M}} Z_{6}{ }^{P}$} \\
\hline \multicolumn{2}{|c|}{ Computed } & \multirow{2}{*}{$\begin{array}{c}\text { Ar matrix } \\
\\
\begin{array}{l}v \sim, \\
\text { Intensi } \\
\text { ty }^{\mathbf{a}}\end{array} \\
\end{array}$} & \multicolumn{2}{|l|}{ Computed } & \multirow{2}{*}{$\begin{array}{l}\begin{array}{l}\text { Ar } \\
\text { matrix }\end{array} \\
\mathcal{v}, \\
\begin{array}{l}\text { Intensi } \\
\text { ty }\end{array}\end{array}$} & \multicolumn{2}{|c|}{ Computed } & \multirow{2}{*}{$\begin{array}{l}\begin{array}{l}\text { Ar } \\
\text { matrix }\end{array} \\
v \sim, \\
\begin{array}{l}\text { Intens } \\
\text { ty }^{\mathbf{a}}\end{array}\end{array}$} \\
\hline$v \sim$ & $I$ & & $v \sim$ & $I$ & & $v \sim$ & $I$ & \\
\hline $\begin{array}{l}1,681 \\
.9\end{array}$ & $\begin{array}{l}297 . \\
6\end{array}$ & $\begin{array}{l}1,696 \\
\text { vs }\end{array}$ & $\begin{array}{l}1,687 \\
.9\end{array}$ & $\begin{array}{l}289 . \\
7\end{array}$ & $\begin{array}{l}1,706 \\
\mathrm{~m}, \mathrm{sh}\end{array}$ & $\begin{array}{l}1,686 \\
.6\end{array}$ & $\begin{array}{l}229 . \\
5\end{array}$ & $\begin{array}{l}1,706 \\
\mathrm{~m}, \mathrm{sh}\end{array}$ \\
\hline $\begin{array}{l}3,251 \\
.1\end{array}$ & $\begin{array}{l}473 . \\
2\end{array}$ & $\begin{array}{l}3,253 \\
\mathrm{~m}\end{array}$ & $\begin{array}{l}3,401 \\
.4\end{array}$ & 75.6 & $\begin{array}{l}3,393 \\
w, \text { ur }\end{array}$ & $\begin{array}{l}3,420 \\
.9\end{array}$ & 74.0 & $\begin{array}{l}3,393 \\
\text { w, ur }\end{array}$ \\
\hline $\begin{array}{l}3,387 \\
.9\end{array}$ & 95.9 & $\begin{array}{l}3,393 \\
w, \text { ur }\end{array}$ & $\begin{array}{l}3,453 \\
.3\end{array}$ & 28.6 & $\begin{array}{l}3,463 \\
w, \text { ur }\end{array}$ & $\begin{array}{l}3,470 \\
.3\end{array}$ & 22.1 & $\begin{array}{l}3,463 \\
\text { w, ur }\end{array}$ \\
\hline $\begin{array}{l}3,460 \\
.1\end{array}$ & 25.3 & $\begin{array}{l}3,463 \\
\text { w, ur }\end{array}$ & $\begin{array}{l}3,470 \\
.9\end{array}$ & 20.6 & $\begin{array}{l}3,463 \\
w, \text { ur }\end{array}$ & $\begin{array}{l}3,471 \\
.2\end{array}$ & 28.9 & $\begin{array}{l}3,463 \\
\text { w, ur }\end{array}$ \\
\hline
\end{tabular}

${ }^{\mathrm{a}} w$ weak, $m$ medium, $s$ strong, $v s$ very strong, sh shoulder, ur unresolved bands 